Portland State University

PDXScholar

\title{
Deformation and Thermal Histories of Ordinary Chondrites: Evidence for Postdeformation Annealing and Syn-Metamorphic Shock
}

\author{
Alexander M. Ruzicka \\ Portland State University, ruzickaa@pdx.edu \\ Richard Hugo \\ Portland State University \\ Melinda Hutson \\ Portland State University
}

Follow this and additional works at: https://pdxscholar.library.pdx.edu/geology_fac

Part of the Geology Commons

Let us know how access to this document benefits you.

\section{Citation Details}

Ruzicka, A., Hugo, R., \& Hutson, M. (2015). Deformation and thermal histories of ordinary chondrites: Evidence for post-deformation annealing and syn-metamorphic shock. Geochimica et Cosmochimica Acta, 163, 219-233.

This Post-Print is brought to you for free and open access. It has been accepted for inclusion in Geology Faculty Publications and Presentations by an authorized administrator of PDXScholar. Please contact us if we can make this document more accessible: pdxscholar@pdx.edu. 


\section{Accepted Manuscript}

Deformation and thermal histories of ordinary chondrites: Evidence for postdeformation annealing and syn-metamorphic shock

Alex Ruzicka, Richard Hugo, Melinda Hutson

PII: S0016-7037(15)00236-7

DOI: http://dx.doi.org/10.1016/j.gca.2015.04.030

Reference: GCA 9236

To appear in:

Geochimica et Cosmochimica Acta

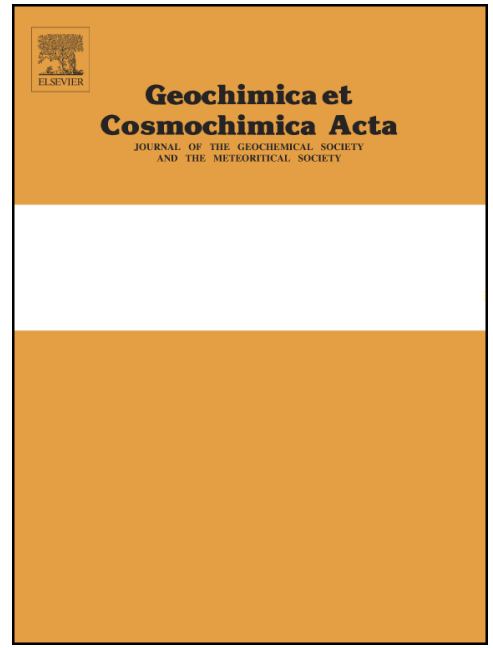

Received Date: $\quad 27$ October 2014

Accepted Date: $\quad 17$ April 2015

Please cite this article as: Ruzicka, A., Hugo, R., Hutson, M., Deformation and thermal histories of ordinary chondrites: Evidence for post-deformation annealing and syn-metamorphic shock, Geochimica et Cosmochimica Acta (2015), doi: http://dx.doi.org/10.1016/j.gca.2015.04.030

This is a PDF file of an unedited manuscript that has been accepted for publication. As a service to our customers we are providing this early version of the manuscript. The manuscript will undergo copyediting, typesetting, and review of the resulting proof before it is published in its final form. Please note that during the production process errors may be discovered which could affect the content, and all legal disclaimers that apply to the journal pertain. 


\section{Deformation and thermal histories of ordinary chondrites:}

\section{Evidence for post-deformation annealing and syn- metamorphic shock}

Alex Ruzicka ${ }^{1,2^{*}}$, Richard Hugo ${ }^{1}$, and Melinda Hutson ${ }^{1,2}$

${ }^{1}$ Portland State University, Department of Geology, 1721 SW Broadway, Portland, OR, U.S.A.

${ }^{2}$ Cascadia Meteorite Laboratory, Portland State University, 1721 SW Broadway, Portland, OR, U.S.A.

${ }^{*}$ Corresponding author. Tel. 503-725-3372, email ruzickaa@pdx.edu

Submitted to Geochimica et Cosmochimica Acta

1 Table, 7 Figures, Electronic Annex.

April 23, 2015 
Abstract-- We show that olivine microstructures in seven metamorphosed ordinary chondrites of different groups studied with optical and transmission electron microscopy can be used to evaluate the post-deformation cooling setting of the meteorites, and to discriminate between collisions affecting cold and warm parent bodies. The L6 chondrites Park (shock stage S1), Bruderheim (S4), Leedey (S4), and Morrow County (S5) were affected by variable shock deformation followed by relatively rapid cooling, and probably cooled as fragments liberated by impact in near-surface settings. In contrast, Kernouvé (H6 S1), Portales Valley (H6/7 S1), and MIL 99301 (LL6 S1) appear to have cooled slowly after shock, probably by deep burial in warm materials. In these chondrites, post-deformation annealing lowered apparent optical strain levels in olivine. Additionally, Kernouvé, Morrow County, Park, MIL 99301, and possibly Portales Valley, show evidence for having been deformed at an elevated temperature $\left(\geq 800-1000{ }^{\circ} \mathrm{C}\right)$.

The high temperatures for Morrow County can be explained by dynamic heating during intense shock, but Kernouvé, Park, and MIL 99301 were probably shocked while the $\mathrm{H}$, $\mathrm{L}$ and $\mathrm{LL}$ parent bodies were warm, during early, endogenically-driven thermal metamorphism. Thus, whereas the S4 and S5 chondrites experienced purely shockinduced heating and cooling, all the S1 chondrites examined show evidence for static heating consistent with either syn-metamorphic shock (Kernouvé, MIL 99301, Park), post-deformation burial in warm materials (Kernouvé, MIL 99301, Portales Valley), or both. The results show the pitfalls in relying on optical shock classification alone to infer an absence of shock and to construct cooling stratigraphy models for parent bodies. Moreover, they provide support for the idea that "secondary" metamorphic and "tertiary" 
shock processes overlapped in time shortly after the accretion of chondritic planetesimals, and that impacts into warm asteroidal bodies were common.

\section{INTRODUCTION}

Collisions affected all solar system bodies and could have played a possibly complex and important role in the geological evolution of low-gravity, asteroidal-sized planetesimals (Scott et al., 1989; Stöffler et al., 1988). Chondritic meteorites are samples of such planetesimals that potentially can record evidence in their microstructures for collisional shock, during and shortly after accretion and in much later events. The $\mathrm{L}$ chondrite parent body evidently suffered a major impact $\sim 0.5 \mathrm{Ga}$ ago that largely destroyed it, and which caused much debris to be delivered to Earth shortly thereafter (Haack et al., 1996; Schmitz et al., 2001; Greenwood et al., 2007; Swindle et al., 2014). There is radiometric evidence that, based on $\mathrm{H}$ chondrites of low optical shock stage (S1 and S2-Stöffler et al., 1991), the H-group parent body initially cooled in an onion-shell structure (Trieloff et al., 2003; Kleine et al., 2008) and that this body was preserved intact during cooling from peak metamorphism. However, there is also evidence that chondrite parent bodies experienced early collisions while they were thermally metamorphosed (e.g., Ruzicka et al., 2005; Hutson et al., 2009; Friedrich et al., 2013, 2014; Tait et al., 2014; Scott et al., 2014). Impact redistribution could have placed chondrites of different metamorphic grades (petrographic types) at different depths, accounting for an overall lack of correlation between these grades and cooling rates based on metallographic techniques (Scott and Rajan, 1981; Grimm, 1985; Taylor et al., 1987; Scott et al., 2014). Especially large early impacts could have resulted in destruction and reassembly of the parent bodies (Grimm, 1985; Taylor et al., 1987; 
47 Ganguly et al. 2013). Optical petrographic properties of olivine provide the main way to assess the shock histories of chondrites (and other meteorites) with the Stöffler et al. (1991) shock stage scheme, which is used widely. However, generally fast diffusion in olivine might allow deformation features to preferentially "heal" in this mineral during annealing (Rubin 1992, 1994, 1995, 2002, 2003, 2004). If so, the shock stage of olivine

52 alone might lead to erroneous inferences.

This study was designed to better understand the role and effect of collisions in the early solar system, especially the relationship between deformation and thermal processing. Transmission electron microscopy (TEM) studies of olivine in ordinary chondrites was our main focus, given the usefulness of TEM to probe shock and thermal histories in chondrites (e.g., Ashworth and Barber, 1975, 1977; Joreau et al., 1997; Langenhorst et al., 1995; Leroux, 2001), and given knowledge of how olivine responds to deformation and annealing (e.g., Raleigh, 1968; Carter et al., 1968; Phakey ey al., 1972; Goetze and Kohlstedt, 1973; Green, 1976; Guegen and Nicolas, 1980;

Druiventak et al., 2011). Ordinary chondrites of different groups but similar petrographic type were selected for study, including L6 (Bruderheim, Leedey, Morrow County, Park), H6 (Kernouvé), H6/7 (Portales Valley), and LL6 (Miller Range 99301, hereafter abbreviated MIL 99301). The L6 chondrites were chosen as reference (baseline) samples, to understand the effects of differing shock intensity ranging from shock stage S1 (Park) to S5 (Morrow County). If the L6 chondrites were shocked late in a parent body break-up event, they could have experienced a simple shock history involving deformation and heating of cold materials followed by rapid cooling. In contrast, the chosen H (Kernouvé, Portales Valley) and LL (MIL 99301) chondrites, all weakly 
deformed (S1), were selected based on evidence that they could have experienced a more complex shock history, involving warm ambient conditions during or after shock. Each contains features that could be relicts of shock metamorphism which were not obliterated during annealing (Rubin, 2004). Coarse metal veins in the $\mathrm{H}$ chondrites such as Portales Valley and Kernouvé likely formed by impact melting and mobilization of metal (Hutson, 1989; Kring et al., 1999; Rubin et al., 2001) before or during metamorphism (Hutson, 1989; Ruzicka et al., 2005; Friedrich et al., 2013). Other potential relict shock features include chromite-plagioclase assemblages in all three meteorites (although these are present in most ordinary chondrites) (Rubin, 2003, 2004), silicate darkening in MIL 99301 and Portales Valley, low-Ca clinopyroxene in MIL 99301, and polycrystalline (recrystallized) troilite in MIL 99301 (Rubin, 2002, 2004).

Preliminary data were reported previously (Hutson et al., 2007, 2009; Ruzicka and Hugo, 2011, 2014).

\section{SAMPLES AND METHODS}

Samples were studied at Portland State University with optical microscopy using a Leica DM 2500 petrographic microscope, and with TEM using an FEI Tecnai G3 transmission electron microscope. Sample designations for meteorites studied with these techniques are given in Tables EA-1 and EA-2 (Electronic Annex). For each meteorite, optical and TEM data were acquired from the same polished thin section. Optical microscopy was used to perform a grain-by-grain assessment of olivine deformation for a representative sampling of grains $\geq 50 \mu \mathrm{m}$ across using the method of Jamsja and Ruzicka (2010). Based on the works of Stöffler et al. (1991), Schmitt and Stöffler (1995) and Schmitt (2000), olivine grains were assigned to different shock 
stages based on intragranular misorientation and the presence of parallel straight planar fractures or planar deformation features (Table EA-1). Misorientation angles were the primary categorization tool, and were determined in cross-polarized transmitted light by the difference in extinction position between the main extinction portion of the grains and their remaining portions. These data were used to determine the conventional shock stage (the highest category shown by at least $25 \%$ of grains, as given by Stöffler et al., 1991), the "weighted shock stage" (the mean of all grain shock stages), and the non-uniformity of deformation (variation of grain shock stages).

The TEM, operated at $200 \mathrm{kV}$, was used to study all electron transparent areas of olivine grains in ion-milled 3-mm-diameter discs cored from polished thin sections. Amplitude contrast imaging in both bright field (bf) and $\mathbf{g}-3 \mathbf{g}$ weak beam dark field (wbdf) mode was used. Parameters were measured that have been found to be related to extent and temperature of deformation, and the extent of annealing. Deformation temperature is indicated by dislocation Burgers vector (b), screw/edge character, and curvature. Long, straight $\mathbf{b}=[001]$ screw dislocations in olivine are characteristic of lowtemperature (and also high strain-rate) deformation, whereas $\mathbf{b}=[001]$ dislocations with more edge or mixed components, dislocation loops, and especially dislocations with slip direction $\mathbf{b}=[100]$ are characteristic of higher temperature (and also low strain-rate) deformation (Raleigh, 1968; Carter et al., 1968; Phakey et al., 1972; Blacic and Christy, 1973; Green, 1976; Ashworth and Barber, 1975, 1977; Guegen and Nicolas, 1980; Gaboriaud et al., 1981; Sears et al., 1984; Töpel-Schadt and Müller, 1985; Langenhorst et al., 1995; Druiventak et al., 2011; Demouchy, et al., 2013). Impact-related deformation involves high strain rates (e.g., Spray, 2010), so temperature is probably 
116 the main variable that determines which slip system will be activated in chondritic

117 olivine. The ratio of "free" dislocations (not "bound" in subgrain boundaries) to the total

118 number of dislocations (free/(free+bound) or FFB ratio) is related to annealing extent

119 (Goetze and Kohlstehdt, 1973). For each discrete olivine grain in our specimens we

120 determined the dislocation density (number per area); $\mathbf{b}$ where possible using the

121 conventional $\mathbf{g} \cdot \mathbf{b}=0$ criterion; for $\mathbf{b}=[001]$ dislocations, the apparent length in screw

122 orientation compared to other orientations ( $\% \mathbf{b}=[001]$ screw sense); qualitative

123 dislocation curvature and symmetry; and the presence of dislocation loops, jogs, and

124 kink bands. For each meteorite specimen we also report the geometric average

125 dislocation density of all olivine grains $\left(\rho_{g}\right)$ rather than arithmetic average because

126 dislocation densities in some specimens vary by orders of magnitude from grain to

127 grain.

128

129

\subsection{Optical petrography}

Optical data are summarized in Table EA-1 (Electronic Annex) and by shock

131 stage histograms in Fig. 1. The meteorites fall into two overall groups: weakly deformed

132 S1 (Portales Valley, Kernouvé, Park, MIL 99301) and more strongly deformed S4

133 (Leedey, Bruderheim) and S5 (Morrow County) chondrites (Fig. 1). Leedey is

134 reclassified as shock stage S4, revised from the literature value of S3 (Rubin, 1994).

135 MIL 99301 is evidently a breccia, containing mostly weakly deformed (S1) but also

136 some more deformed and even recrystallized (S6) grains (Fig. 1). Some meteorites

137 (e.g., Leedey) show less dispersion in shock stages, and on this basis provide no

138 evidence for being breccias or for having been impacted more than once. Morrow 
139 County is a definite S5 based on olivine data, consistent with the presence in this 140 meteorite (alone among the samples studied) of all feldspar as maskelynite, a hallmark 141 of shock stage S5 (Stöffler et al., 1991). Morrow County also contains numerous 142 chromite-plagioclase (maskelynite) assemblages, a proposed shock indicator (Rubin, 143 2003), as well as prominent shock veins.

All the $\mathrm{S} 1$ meteorites contain otherwise unstrained olivine grains that have sharply defined low-angle misorientation boundaries observable with optical

146 microscopy, with orientation mismatches of a few degrees from one side of the 147 boundary to the other. Fig. 2 shows an example of such a grain from Portales Valley. 148 These grains do not fit readily into shock stage categories: misorientation of this extent 149 should be accompanied by planar fractures or planar deformation features, and/or by 150 151 produced by annealing, either by adjacent olivine grains growing together in nearly the same crystallographic orientation during metamorphism, or by deformed single grains generating orientation domains as a result of dislocation climb during annealing (to form 154 subgrain boundaries). Sharp changes in orientation also could be a manifestation of 155 kink bands produced by deformation (Raleigh, 1968; Carter et al., 1968). As noted 156 below, olivine TEM data indicate that subgrain boundaries are common in Kernouvé, 157 Portales Valley, and MIL 99301, and that kink bands are present in Park and MIL 15899301 . Thus the olivine misorientation features noted optically in these meteorites are 159 probably subgrain boundaries in Kernouvé, Portales Valley, and MIL 99301, and kink 160 bands in Park. 


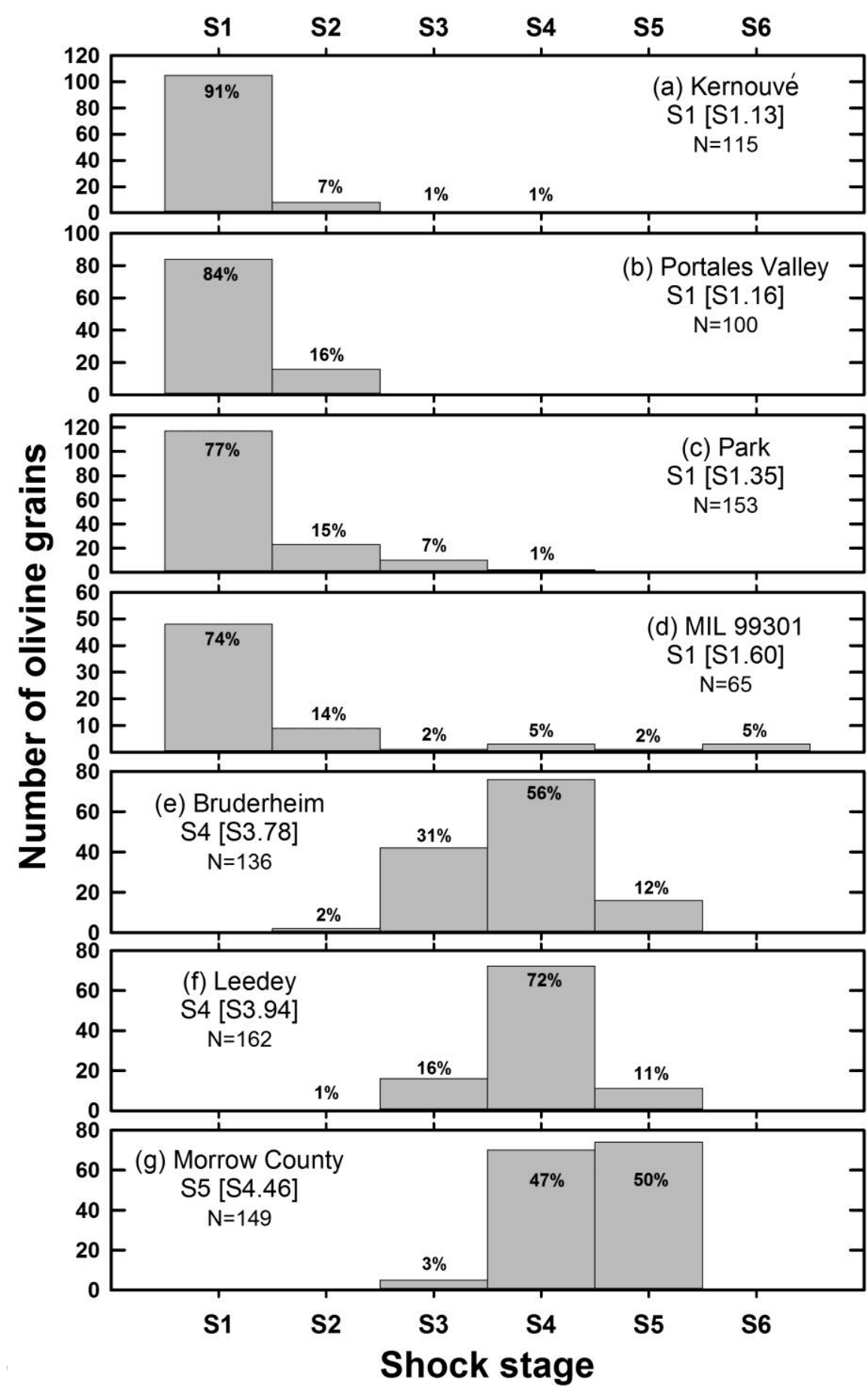

Fig. 1. Shock stage histograms for the meteorites in this study, arranged according to increasing weighted shock stage (values in brackets; the conventional shock stage from the $25 \%$ rule is shown outside the brackets). $\mathrm{N}=$ number of grains.

[color in web, b/w in print]

161 

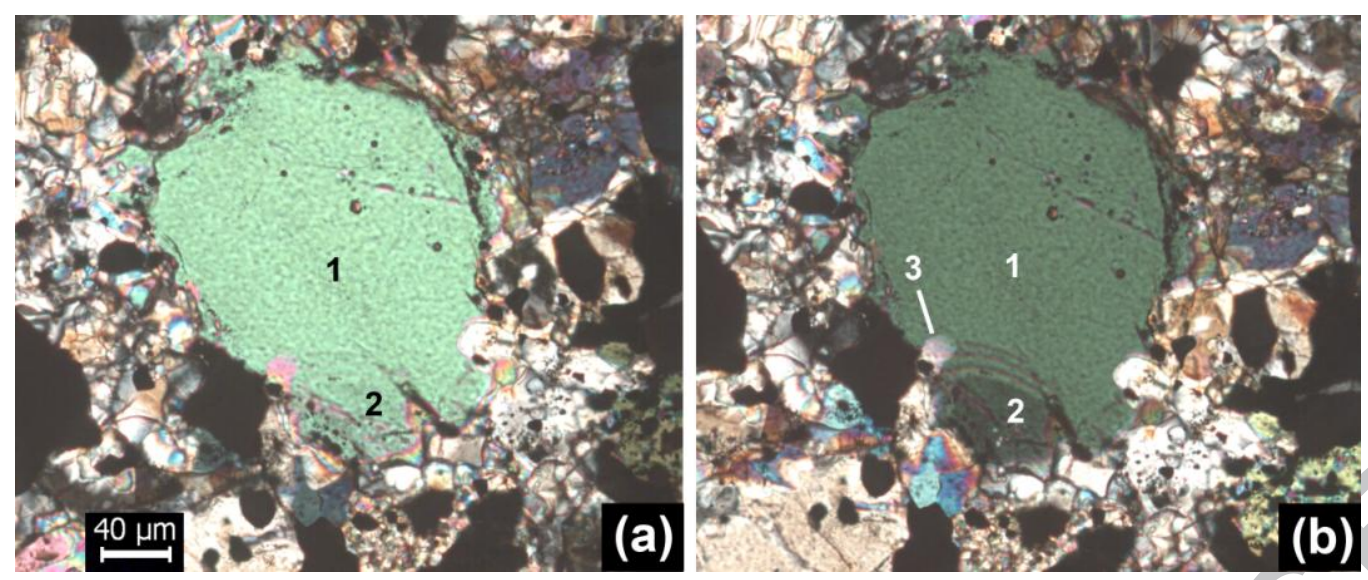

Fig. 2. Cross-polarized transmitted light images of an otherwise weakly strained olivine grain in Portales Valley (CML0056-3) for two stage positions (part b rotated $15^{\circ}$ clockwise relative to part a), showing a low angle $\left(\sim 5^{\circ}\right)$ misorientation boundary between areas 1 and 2 . The misorientation boundary is invisible in part $a$, but visible in part $b$ as a sharp and slightly curved feature; fringes suggest a dipping contact. Area 3 is another orientation domain within the grain. Scale bar is $40 \mu \mathrm{m}$ long. [color in web, black/white in print]

\subsection{TEM petrography}

TEM results are summarized in Table 1 and reported for individual olivine grains in Table EA-2 (Electronic Annex). Representative TEM micrographs are shown for L6 chondrites in Fig. 3, and for Hand LL chondrites in Fig. 4.

\subsubsection{Leedey and Bruderheim (L6 S4)} deformed (average geometric dislocation density $\rho_{\mathrm{g}} \sim 3 \times 10^{9}$ and $\sim 1 \times 10^{10} \mathrm{~cm}^{-2}$, respectively) with a strong prevalence of $\mathbf{b}=[001]$ dislocations, and only rare subgrain

172 boundaries (Table 1; Fig. 3a-d). Dislocations are relatively straight, and include both screw and edge components, typically forming a rectilinear pattern (Fig. 3a, c). In many cases the individual dislocations take the form of a larger glide loop, with parallel $\mathbf{b}=[001]$ screws and more rounded edge segments. "Walls" of dislocation tangles are

176 present across which misorientation of the crystal lattice occurs, forming patchy

177 domains ( $\leq 1 \mu \mathrm{m}$ across) of differing crystal orientation between the walls (Fig. 3b). The 
178 walls themselves can be straight, curved, or en echelon (Fig. 3g). Leedey also contains

179 kink bands that produced lamellar misorientation domains (Fig. 3d). The kink band

180 boundaries are narrower than other misorientation boundaries such as those composed

181 of tangles.

$182 \quad 3.2 .2$. Morrow County (L6 S5)

183 Olivine microstructures in Morrow County resemble those in Bruderheim and

184 Leedey in some ways but differ significantly in other ways. As in Bruderheim and

185 Leedey, olivine in Morrow County is heavily deformed $\left(\rho_{g} \sim 5 \times 10^{9} \mathrm{~cm}^{-2}\right)$ and contains

186 only rare subgrain boundaries (Table 1). Also like Bruderheim and Leedey, a rectilinear

187 pattern of dislocations including $\mathbf{b}=[001]$ screws and edge dislocations was observed

188 (Fig. 3e). Common dislocation tangles (Fig. 3f) form planar and en echelon

189 misorientation boundaries, and micrometer-sized orientation domains are well-

190 developed (Fig. 3g). Unlike Bruderheim and Leedey, Morrow County contains many

191 extensively curved and bowed dislocations and many small dislocation loops (Table 1,

192 Fig. 3f). $\mathbf{b}=[001]$ dislocations with mixed screw/edge character are typical (Fig. 3f).

$193 \mathbf{b}=[100]$ dislocations are common (Table 1), and sometimes form arrays that intersect

194 with $\mathbf{b}=[001]$ dislocations to form dense tangles (Fig. 3f).

195

196

197 
ACCEPTED MANUSCRIPT

Table 1. Summary data for olivine microstructures based on transmission electron microscopy ( $\mathrm{N}=$ number of TEM grains measured).

\begin{tabular}{|c|c|c|c|c|c|c|c|c|c|}
\hline Meteorite & $\begin{array}{l}\text { Geometric } \\
\text { mean } \\
\text { dislocation } \\
\text { density }\left(\rho_{\mathrm{g}}\right) \\
\left(\mathrm{cm}^{-2}\right) \\
\end{array}$ & $\begin{array}{l}\text { Geometric } \\
\text { standard } \\
\text { deviation } \\
\text { dislocation } \\
\text { density }\end{array}$ & $\begin{array}{l}\text { Maximum } \\
\text { dislocation } \\
\text { density } \\
\left(\mathrm{cm}^{-2}\right)\end{array}$ & $\begin{array}{l}\text { Typical } \\
\text { dislocation } \\
\text { microstructure }\end{array}$ & $\begin{array}{l}\text { Subgrain } \\
\text { boundaries }\end{array}$ & $\begin{array}{l}\text { Average FFB } \\
\text { dislocation } \\
\text { ratio }(\%)^{a}\end{array}$ & $\begin{array}{l}\text { b vector } \\
\text { summary }\end{array}$ & $\begin{array}{l}\text { Average } \\
\%[001] \\
\text { screw } \\
\text { dislocations }\end{array}$ & $\mathrm{N}$ \\
\hline Bruderheim & $1.3 \times 10^{10}$ & 4.1 & $1.5 \times 10^{11}$ & $\begin{array}{l}\text { Parallel straight } \\
\text { screw segments, } \\
\text { other areas a } \\
\text { mix of parallel } \\
\text { screws \& } \\
\text { intersecting or } \\
\text { curved; tangles. }\end{array}$ & rare / none & $100 \pm 0$ & [001] prevalent. & $29 \pm 22$ & 12 \\
\hline Leedey & $3.2 \times 10^{9}$ & 2.7 & $2.1 \times 10^{10}$ & $\begin{array}{l}\text { Straight } b=[001] \\
\text { segments in } 3 \\
\text { directions, some } \\
\text { bowing; tangles } \\
\text { \& kink bands. }\end{array}$ & infrequent & $96+4 /-10$ & $\begin{array}{l}\text { [001] prevalent, } \\
{[100] \text { infrequent. }}\end{array}$ & $<50$ & 11 \\
\hline $\begin{array}{l}\text { Morrow } \\
\text { County }\end{array}$ & $4.9 \times 10^{y}$ & 3.2 & $2.4 \times 10^{10}$ & $\begin{array}{l}\text { Extensively } \\
\text { curved \& bowed } \\
\text { with many loops; } \\
\text { common tangles. }\end{array}$ & rare & $99+1 /-3$ & $\begin{array}{l}\text { [001] prevalent, } \\
{[100] \text { common. }}\end{array}$ & $\begin{array}{l}10 \pm 12 \\
(7 \pm 7, N=12)\end{array}$ & 13 \\
\hline Park & $3.3 \times 10^{8}$ & 3.4 & $1.3 \times 10^{9}$ & $\begin{array}{l}\text { Many parallel } \\
\text { straight } \\
\text { segments; } \\
\text { extensively } \\
\text { curved, bowed, } \\
\text { common loops; } \\
\text { tangles \& kink } \\
\text { bands. }\end{array}$ & / none & 100 & $\begin{array}{l}\text { [001] prevalent, } \\
{[100] \text { somewhat }} \\
\text { common. }\end{array}$ & $36 \pm 17$ & 18 \\
\hline Kernouvé & $1.1 \times 10^{6}$ & $4.2 \times 10^{3}$ & $6.8 \times 10^{8}$ & $\begin{array}{l}\text { Bowed individual } \\
\text { dislocations. }\end{array}$ & common & $84+16 /-29$ & $\begin{array}{l}\text { [001] prevalent, } \\
{[100] \text { common. }}\end{array}$ & $2+7 /-2$ & 20 \\
\hline $\begin{array}{l}\text { Portales } \\
\text { Valley }\end{array}$ & $4.4 \times 10^{6}$ & $6.8 \times 10^{3}$ & $1.4 \times 10^{10}$ & $\begin{array}{l}\text { Parallel straight; } \\
\text { some } \\
\text { intersecting, } \\
\text { curved; some } \\
\text { tangles. }\end{array}$ & common & $88+22 /-28$ & $\begin{array}{l}{[001] \text { prevalent, }} \\
{[100] \text { infrequent, }} \\
{[101] \text { rare in }} \\
\text { subgrain } \\
\text { boundaries. }\end{array}$ & $32 \pm 27$ & 30 \\
\hline MIL 99301 & $2.2 \times 10^{\prime}$ & $6.2 \times 10^{2}$ & $1.4 \times 10^{9}$ & $\begin{array}{l}\text { Parallel straight; } \\
\text { frequent } \\
\text { intersecting or } \\
\text { curved; kink } \\
\text { bands. }\end{array}$ & common & $74+26 /-36$ & $\begin{array}{l}\text { [001] prevalent, } \\
{[100] \text { somewhat }} \\
\text { common, [101] } \\
\text { rare in subgrain } \\
\text { boundaries. }\end{array}$ & $56 \pm 26$ & 9 \\
\hline
\end{tabular}

\footnotetext{
${ }^{\mathrm{a}} 100 \times$ (number free dislocations) / (number free + bound dislocations), arithmetic average and standard deviation.

${ }^{b}$ Length of $\mathbf{b}=[001]$ dislocations that are in screw sense, arithmetic average and standard deviation. For Morrow County, two sets of values are shown, one set for all 13 areas examined and one set excluding an atypical area.
} 


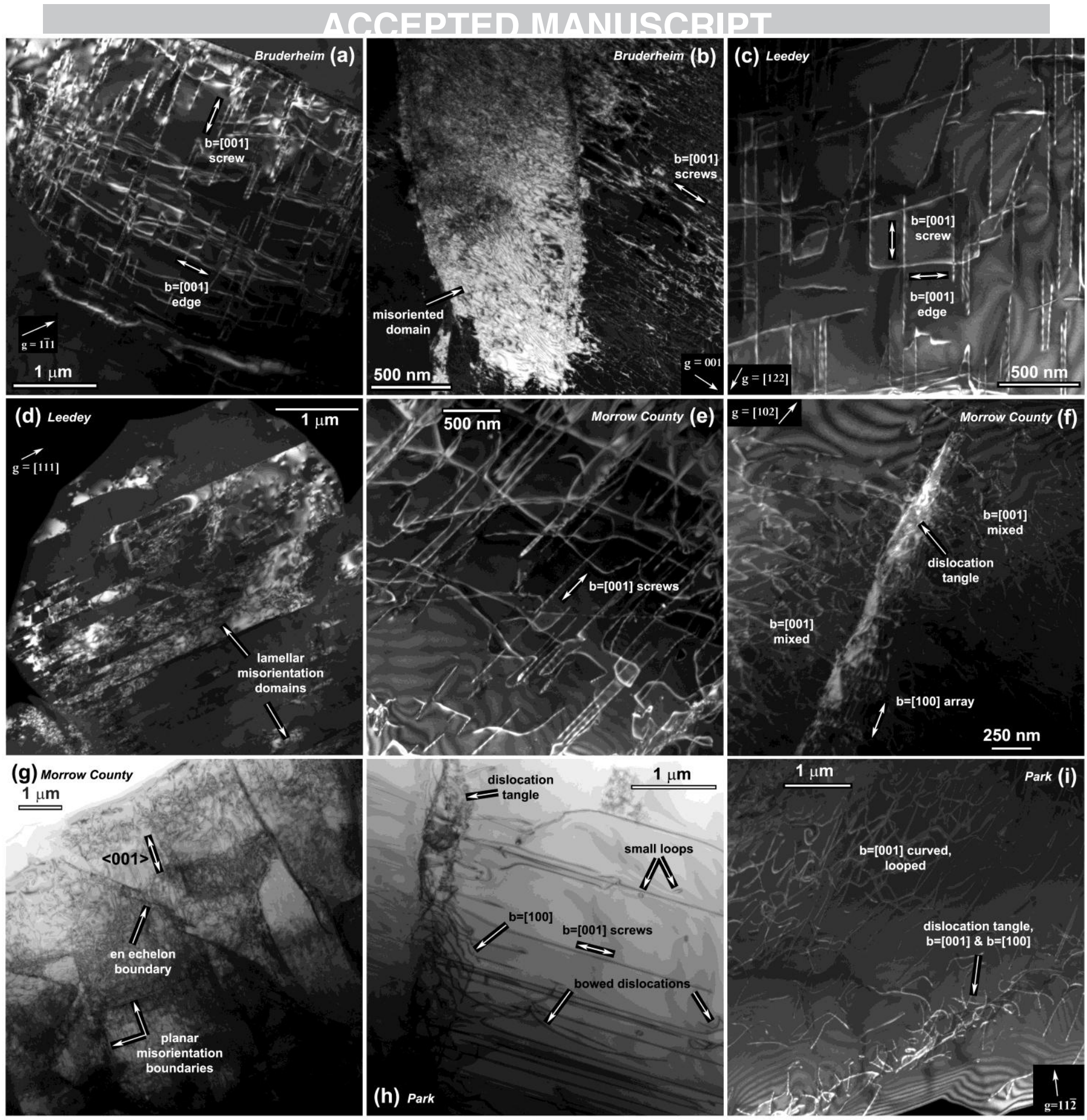

Fig. 3. TEM images of olivine in $L$ chondrites obtained in weak beam dark field ( $w b d f$ ) and bright field (bf) modes. (a, b) Wbdf images of Bruderheim, showing rectilinear pattern of $\mathbf{b}=[001]$ screw and edge dislocations (part $a$ ), and $\mathbf{b}=[001]$ screw dislocations and a misoriented domain (part b). The intense contrast of the latter domain is caused by overlapping strain fields produced by strong deformation. (c, d) Wbdf images of Leedey showing rectilinear pattern of $\mathbf{b}=[001]$ screw and edge dislocations (part $\mathrm{c}$ ), and kink bands producing lamellar misorientation domains (part d). (e) Wbdf image of Morrow County showing presence of $\mathbf{b}=[001]$ screw dislocations and other dislocations with a vaguely rectilinear pattern; curved dislocations are also present. (f) Morrow County observed in wbdf mode showing typical curved, mixed $\mathbf{b}=[001]$ dislocations, and a dislocation tangle composed in part of $\mathbf{b}=[100]$ dislocations. ( $\mathrm{g}$ ) Morrow County observed in bf mode showing planar and en echelon misorientation boundaries, defined by dislocation tangles. Numerous curved dislocations (small dark features) are present throughout. (h) Park observed in bf mode showing $\mathbf{b}=[001]$ screw dislocations, bowed dislocations and small loops, as well as a dislocation tangle composed in part of an array of $\mathbf{b}=[100]$ dislocations. (i) Wbdf image of Park showing curved and looped $\mathbf{b}=[001]$ dislocations and a dislocation tangle composed of both $\mathbf{b}=[100]$ and $\mathbf{b}=[001]$ dislocations. [b/w in web and in print] 


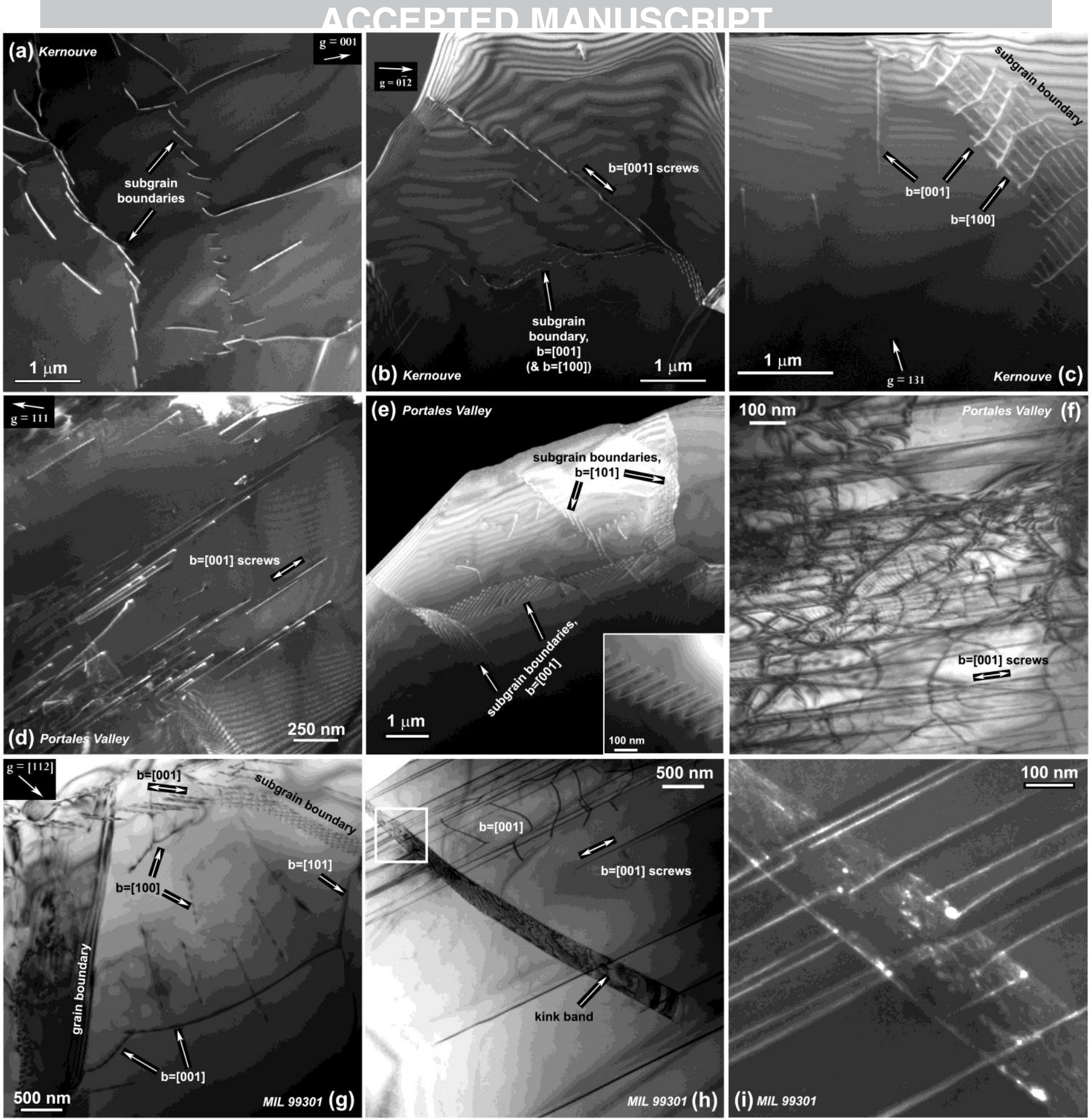

Fig. 4. TEM images of olivine in $\mathrm{H}$ and LL chondrites. ( $(\mathrm{a}, \mathrm{b}, \mathrm{c})$ Wbdf images of Kernouvé showing relatively low dislocation density, and subgrain boundaries that range from poorly developed (part a, one set of dislocations) to well-developed two-set "picket fence" (part c). Both $\mathbf{b}=[001]$ and $\mathbf{b}=[100]$ dislocations are present. (d) Wbdf image of Portales Valley showing moderate density of $\mathbf{b}=[001]$ screw dislocations and no subgrain boundaries. (e) Bf image of Portales Valley showing virtually all dislocations present in subgrain boundaries, composed of both $\mathbf{b}=[001]$ and $\mathbf{b}=[101]$ dislocations. The inset shows a wbdf image close-up of a subgrain boundary in Portales Valley composed of one set of parallel and nearly straight dislocations. (f) Bf image of a relatively deformed area of Portales Valley including $\mathbf{b}=[001]$ screw dislocations. (g) Wbdf image of MIL 99301 showing both $\mathbf{b}=[100]$ and $\mathbf{b}=[001]$ dislocations as well as some $\mathbf{b}=[101]$ dislocations and a subgrain boundary. (h) Bf image of MIL 99301 showing $\mathbf{b}=[001]$ dislocations including many in screw configuration, as well as a kink band with a terminal $\mathbf{b}=[100]$ dislocation. The box shows the location of part i. (i) Wbdf image showing a close up of the kink band in part $h ; \mathbf{b}=[001]$ dislocations are jogged across the kink band. [b/w in web and print] 
144

145

146

147

148

149

150

151

152

153

154

155

156

157

158

159

160

161

162

163

164

165

166

\subsubsection{Park (L6 S1)}

Olivine in Park is less deformed $\left(\rho_{g} \sim 3 \times 10^{8} \mathrm{~cm}^{-2}\right)$ than in the previously described $L$ chondrites. As with these other chondrites, subgrain boundaries are essentially absent (Table 1 ). Dislocations include many straight $\mathbf{b}=[001]$ screws, as in Bruderheim and Leedey, but also many extensively curved or bowed dislocations and some small loops (Fig. 3h, 3i), as in Morrow County. $\mathbf{b}=[100]$ dislocations, though not as common as in Morrow County, are also present in Park, and as in Morrow County, such $\mathbf{b}=[100]$ dislocations are found in dislocation tangles (Fig. 3h, i). Kink bands were observed.

\subsubsection{Kernouvé (H6 S1)}

This chondrite contains the least deformed olivine, on average, of those studied $\left(\rho_{g} \sim 1 \times 10^{6} \mathrm{~cm}^{-2}\right)$, with many grains nearly devoid of dislocations and others having only a modest number (Fig. 4a-c). Unlike the other chondrites mentioned so far, subgrain boundaries are prominent in olivine from Kernouvé. These subgrain boundaries range in their configurations from those with only one set of loosely arranged, non-intersecting dislocations (Fig. 4a) to those with two sets of intersecting dislocations forming a curvilinear "picket fence" (Fig. 4c). Intermediate cases of subgrain boundaries with only a few intersecting dislocations are present (Fig. 4b). Some parallel $\mathbf{b}=[001]$ screws are found in Kernouvé (Fig. 4b), but most dislocations are bowed or curved, or are present in subgrain boundaries. $\mathbf{b}=[100]$ dislocations are common, and are often found in subgrain boundaries (Fig. 4b, c). 


\subsubsection{Portales Valley (H6/7 S1)}

Olivine grains in Portales Valley have diverse microstructures. Dislocation densities vary greatly in grains, from nil to $\sim 10^{10} \mathrm{~cm}^{-2}$. Averaging over many (30) grains, the overall dislocation density is low in Portales Valley $\left(\rho_{\mathrm{g}} \sim 4 \times 10^{6} \mathrm{~cm}^{-2}\right)$ and only slightly more than in Kernouvé (Table 1). Dislocations with $\mathbf{b}=[001]$ are most common, but infrequent $\mathbf{b}=[100]$ were observed. Rare $\mathbf{b}=[101]$ dislocations were found in subgrain boundaries. In some grains, straight $\mathbf{b}=[001]$ screws are present in moderately (Fig. $4 d$ ) or heavily deformed grains (Fig. 4f), whereas other grains contain curved or tangled dislocations, or subgrain boundaries (Fig. 4e). In some subgrain boundaries, dislocations are notably straight and parallel and contained in a tight band (inset Fig. 4e), indicating better developed subgrains than in Kernouvé. Some subgrain boundaries consist mainly of $\mathbf{b}=[001]$ dislocations, whereas others consist mainly of $\mathbf{b}=[101]$ dislocations (Fig. 4e). The $\mathbf{b}=[101]$ dislocations likely formed by the combination of $\mathbf{b}=[001]$ and $\mathbf{b}=[100]$ dislocations during climb.

\subsubsection{MIL 99301 (LL6 S1)}

Olivine in MIL 99301 has a low overall dislocation density $\left(\rho_{g} \sim 2 \times 10^{7} \mathrm{~cm}^{-2}\right)$ (Table 1). Dislocations include straight $\mathbf{b}=[001]$ screws (Fig. 4h), somewhat common $\mathbf{b}=[100]$ dislocations (Fig. $4 \mathrm{~g}$ ), rare $\mathbf{b}=[101]$ dislocations in areas close to $\mathbf{b}=[001]$ and $\mathbf{b}=[100]$ dislocations (Fig. 4g), and curved dislocations of all types (Fig. 4g, h). As with Portales Valley, the $\mathbf{b}=[101]$ dislocations likely formed by the combination of $\mathbf{b}=[001]$ and $\mathbf{b}=[100]$ dislocations during climb. Some dislocations are jogged, evidence for the movement of one dislocation through another. MIL 99301 olivine also contains a kink band (Fig. 4h) whose terminus is marked by $\mathbf{a} \mathbf{b}=[100]$ dislocation. $\mathbf{b}=[001]$ screw 
190 dislocations are jogged where they intersect with the kink band (Fig. 4i), evidence for

191 the movement of one or more dislocations through the screws. Subgrain boundaries in

192 MIL 99301 include "picket fence" and single dislocation sets (Fig. 4g), as in Kernouvé

193 and Portales Valley, and contain $\mathbf{b}=[001]$ and $\mathbf{b}=[101]$ dislocations, as in Portales

194 Valley.

\section{DISCUSSION}

\subsection{Annealing (recovery) during and after shock}

Microstructures in olivine can be used to evaluate annealing (microstructural recovery) effects, both as a result of dynamic heating (during shock deformation) and as a result of static heating (post-impact heating). Features produced by annealing include curved dislocations, small dislocation loops, "picket fence" subgrain boundaries, annihilation of dislocations, and healing of cracks (e.g., Phakey et al., 1972; Goetze and Kohlstedt, 1973; Ashworth and Mallinson, 1985).

Fig. 5 shows a large difference in olivine between the reference L6 chondrites

(Park, Leedey, Bruderheim, Morrow County) and those that were purportedly annealed

(Kernouvé, Portales Valley, MIL 99301), in terms of such parameters as the average dislocation density, the weighted shock stage, and the FFB dislocation ratio. The

207 reference $\mathrm{L} 6$ chondrites show a crude correlation between dislocation density and shock stage, but the annealed chondrites have low dislocation densities that do not correlate with shock stage (Fig. 5a). In addition, the FFB ratio for the reference chondrites lies close to 1 (0.96-1.0, i.e., there are few subgrain boundaries in them),

211 whereas the FFB ratio is significantly lower in the annealed chondrites (0.74-0.88) (Fig. 
$2125 b)$. Among all the meteorites, dislocation density and FFB ratio are correlated, with the

213 annealed chondrites having both low FFB and low dislocation density (Fig. 5b).

The latter correlation is the trend expected for microstructural recovery involving

215 dislocation climb and annihilation (Fig. 5b). This implies that the low dislocation

216 densities in Kernouvé, Portales Valley, and MIL 99301 were produced by significant

217 recovery, and supports the identification of these chondrites as extensively annealed.

218 The subgrain boundaries that are present in Kernouvé, Portales Valley, and MIL 99301

219 must be the result of post-shock annealing not directly related to their impact heating,

220 because the annealing effects associated with even strongly shocked (S4 and S5)

221 chondrites are minor. This implies that annealing was caused by endogenic heat.

222 The dislocation climb necessary for subgrain boundary formation is thermally

223 activated and related to both the time and temperature of annealing (see below). As

224 there is no relationship between FFB ratio and shock stage or dislocation density for the

225 reference L6 chondrites, which were presumably shocked to different temperatures,

226 annealing time must be the critical variable, and longer annealing times for Kernouvé,

227 Portales Valley, and MIL 99301 can be surmised. Thus, one can infer rapid cooling after

228 deformation for the $L 6$ chondrites, and slow cooling after deformation for the annealed

229 chondrites. The extended post-deformation annealing for Kernouvé, Portales Valley,

230 and MIL 99301 implies deep burial from a cooling surface, and possibly emplacement in

231 a large mass of warm materials. In contrast, all the L6 chondrites evidently cooled more

232 rapidly after deformation, as a result of shallow burial from a cooling surface. 


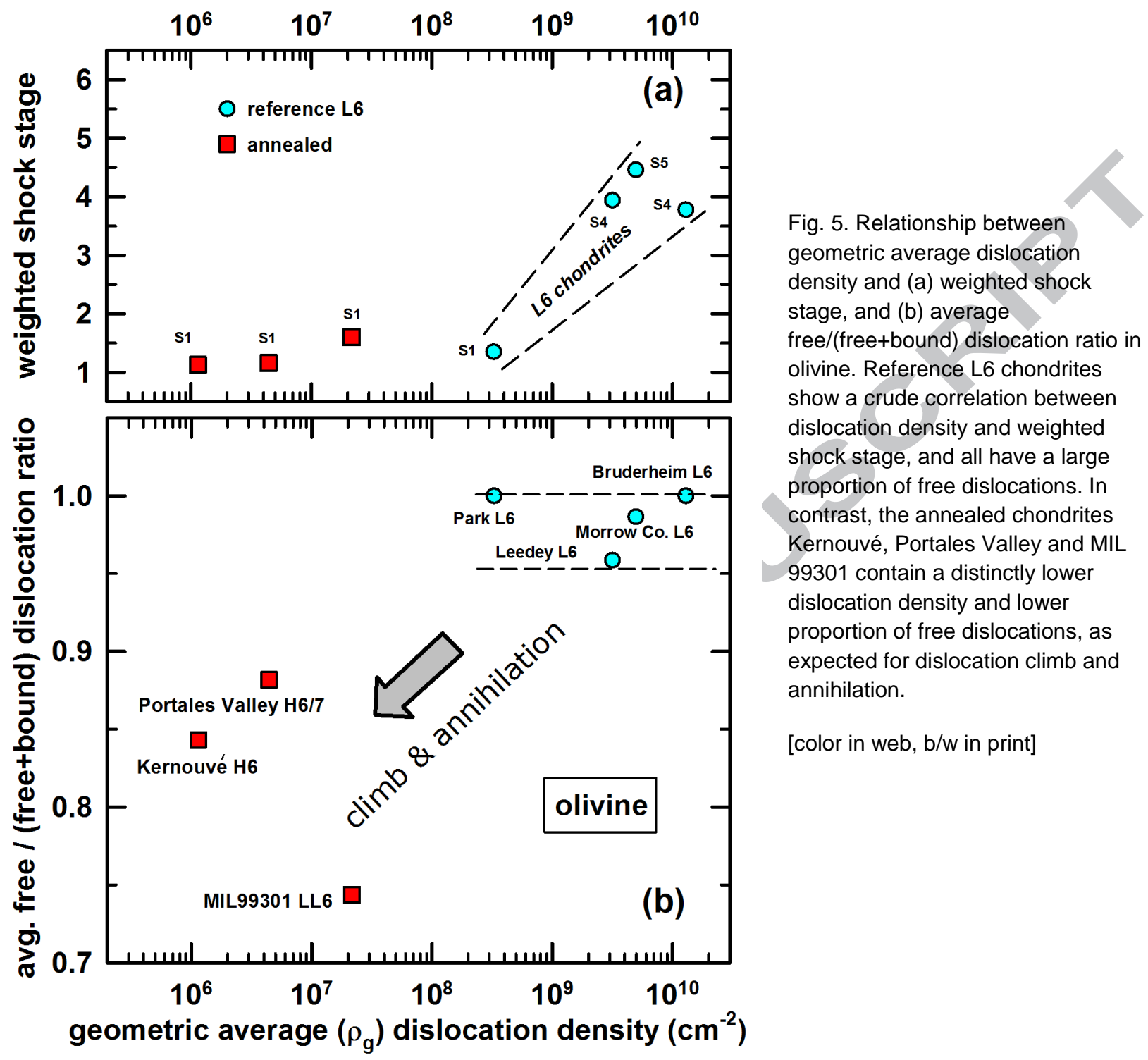
In principle, the time-temperature conditions necessary to create subgrain

236 boundaries in Kernouvé, Portales Valley, and MIL 99301 can be evaluated using the experimental data of Goetze and Kohlstedt (1973), but in practice it appears no firm

238 conclusion can be drawn from these data. The experiments related a decrease in

239 free/bound dislocation ratio to annealing temperatures and times through an Arrhenius 
241 histories of shocked chondrites (Ashworth and Mallinson, 1985), the validity of the

242 Arrhenius constants are uncertain, and other work suggests possibly slower rates of

243 recovery, by roughly 1-2 orders of magnitude (Guegen and Nicholas, 1980). Allowing for

244 two orders of magnitude slower recovery, annealing durations of tens of hours (at

$2451000^{\circ} \mathrm{C}$ ) to hundreds of years (at $800^{\circ} \mathrm{C}$ ) are implied for the annealed chondrites,

246 assuming a decrease in FFB of $25 \%$ (from 1 to 0.75 ). This is much less than the millions

247 of years cooling time needed for a parent body heated by ${ }^{26} \mathrm{Al}$ decay (Trieloff et al.,

248 2003; Kleine et al., 2008), which at face value implies that a ${ }^{26} \mathrm{Al}$ radiogenic heat source

249 cannot be responsible for the post-deformation annealing experienced by the annealed

250 chondrites. However, the result is uncertain. Moreover, in apparent contrast to the

251 natural samples, the experimental charges showed little dislocation annihilation during

252 recovery (Goetze and Kohlstedt, 1973), suggesting the experiments may not be

253 applicable to the annealed chondrites.

Although olivine grains in the strongly shocked chondrites (Leedey, Bruderheim,

255 Morrow County) do not have many subgrain boundaries, there is evidence for significant

256 dislocation climb in Morrow County, including the presence of extensively curved and

257 bowed dislocations and small dislocation loops. These features in Morrow County (S5)

258 compared to Leedey and Bruderheim (both S4) can be explained by higher

259 temperatures during deformation (Phakey et al., 1972), as thermal activation allows

260 dislocations to bow away from the linear configurations defined by Peierls barriers. This

261 explanation is plausible because there is a sharp increase in shock temperature and

262 post-shock temperature with an increase in shock pressure from shock stage S4 to S5

263 (Stöffler et al., 1991; Schmitt, 2000). 
Annealing experiments of shock-deformed olivine show that annealing for 90

265

266

267

268

269

270

271

272

273

274

275

276

277

278

279

280

281

282

283

284

285

hours at $800-900{ }^{\circ} \mathrm{C}$ does not produce subgrain boundaries, but that annealing for this amount of time at $1000^{\circ} \mathrm{C}$ does (Ashworth and Mallinson, 1985). Further, deformation experiments from $600-1250{ }^{\circ} \mathrm{C}$ showed only limited recovery at temperature $<1000{ }^{\circ} \mathrm{C}$ (Phakey et al., 1972). Thus, Morrow County must have experienced a combination of either low shock temperatures $\left(<1000^{\circ} \mathrm{C}\right)$ or short post-shock annealing times $(<90$ hours), or both. For the other rapidly cooled L6 chondrites (Leedey, Bruderheim, Park), post-shock annealing temperatures and durations were even less, probably $<<800{ }^{\circ} \mathrm{C}$ and $<<90$ hours.

Thermal histories of chondrites during and after shock can be evaluated also based on metallographic techniques (e.g., Smith and Goldstein, 1977). For example, Scott et al. (2014) provided an account of cooling histories of low-shock $\mathrm{H}$ chondrites derived from studies of metal, including quantitative estimates of cooling rates based on the central taenite method. This method reflects cooling at temperatures $\left(\sim 500^{\circ} \mathrm{C}\right)$ that are probably much lower than those needed to produce significant recovery in olivine. Thus, metallographic cooling rates might or might not directly correspond to the annealing effects discussed here. Nevertheless, metallographic cooling rates for Kernouvé $\left(10^{\circ} \mathrm{C} / \mathrm{Ma}\right)$ and Portales Valley $\left(25^{\circ} \mathrm{C} / \mathrm{Ma}\right)$, although not unusual, are on the low side for low-shock H chondrites (Scott et al., 2014). This is consistent with deep burial of these meteorites during cooling. These cooling rates could correspond to depths of $\sim 10-15 \mathrm{~km}$ in the $\mathrm{H}$ chondrite parent asteroid (Scott et al., 2014).

\subsection{Shock stages of quickly cooled and annealed chondrites}


The correlation between shock stage and average dislocation density for the L6

287

288

289

290

291

292

293

294

295

296

297

298

299

300

301

302

303

304

305

306

307

308

chondrites (Fig. 5a) is what one would expect for a shock history uncomplicated by

extensive post-deformation recovery. The data imply characteristic dislocation densities

in olivine for substantially unannealed and quickly cooled S4 and S5 chondrites of $\sim 3 x$ $10^{9}$ to $1 \times 10^{10} \mathrm{~cm}^{-2}$, and for $\mathrm{S} 1$ chondrites of $\sim 3 \times 10^{8} \mathrm{~cm}^{-2}$. These densities are

generally consistent with literature values (Ashworth and Barber 1975, 1977; Madon and Poirier, 1983; Töpel-Schadt and Müller, 1985; Ruzicka, 1990; Langenhorst et al., 1995; Leroux et al. 1996; Joreau et al. 1996, 1997).

The highest average dislocation densities were found in Bruderheim, despite this meteorite having a lower conventional shock stage than Morrow County and a lower weighted shock stage than Leedey (Fig. 1, 5). This probably indicates that the region in Bruderheim observed with TEM was slightly more deformed than average for Bruderheim. This variation is not unexpected, as the passage of a shock wave in rocks will produce local variations in shock pressures and temperatures owing to the heterogeneous nature of the rocks (e.g., Sharp and DeCarli, 2006). It is also possible that Morrow County experienced some amount of dislocation annihilation during a limited recovery period.

If the low average dislocation densities for Kernouvé, MIL 99301, and Portales Valley were the result of recovery that destroyed many dislocations (Sec. 4.1), the question arises as to how many dislocations were removed and what shock stage these meteorites may have had originally. Two approaches using dislocation densities in olivine, together with comparisons to the reference chondrites, can be used as guides to the original deformation: the maximum dislocation density (approach 1) and the 
309

310

311

312

313

314

315

316

317

318

319

320

321

322

323

324

325

326

327

328

329

330

331

dislocation densities of areas that contain dislocations but no subgrain boundaries (approach 2). Using approach 1, the maximum dislocation densities $\left(\mathrm{cm}^{-2}\right)$ in Kernouvé, MIL 99301, and Portales Valley are $\sim 7 \times 10^{8}, \sim 1 \times 10^{9}$, and $\sim 1 \times 10^{10}$, respectively (Table 1). These densities are respectively similar to those in Park (S1), between Park and Leedey (i.e., S2-S3), and between Morrow County and Bruderheim (i.e., S4-S5). Using approach 2, the densities are $\sim 6 \times 10^{6}-5 \times 10^{8}$ in Kernouvé and $\sim 6 \times 10^{7}-1 \times$ $10^{9}$ in MIL 99301, both similar to that in Park, whereas Portales Valley has too large a spread $\left(\sim 1 \times 10^{6}-1 \times 10^{10}\right)$ to provide a useful constraint (Fig. EA-1).

Based on these comparisons, we suggest that post-deformation annealing lowered apparent optical strain levels in olivine from Kernouvé, MIL 99301, and (especially) Portales Valley. Kernouvé probably was S1 originally, though a more deformed S1 than it is now. MIL 99301 originally could have been shock stage S2-S3 or a more deformed S1, less than the S4 inferred by Rubin (2002) based on other potential shock indicators. Portales Valley could have been shock stage S4-S5 originally, which is more than the initial S3 inferred by Kring et al. (1999) and Rubin et al. (2001), and less than the S6 mentioned by Rubin (2004).

We have no reason to doubt that among the three annealed chondrites, Kernouvé was the least deformed initially, MIL 99301 next most deformed, and Portales Valley the most deformed, but the estimates of initial shock stages should be considered uncertain. Too little is known still about the correspondence of deformation between TEM and optical methods. The real possibility of multiple impacts or heterogeneous impact effects also can complicate interpretations. In addition, although recovery of modestly deformed (S2 or S3) olivine to produce S1 olivine seems 
332 reasonable, less clear is whether more strongly deformed grains (S4 or S5) could be

333 effectively recovered. For such heavily deformed grains, significant annealing might

334 result in recrystallization instead (Scott et al., 2014).

335

336

337

338

339

340

341

342

343

344

345

346

347

348

349

350

351

352

353

354

\subsection{Temperatures during shock}

Three independent temperature proxies that relate to thermally activated

processes during slip can be used to assess temperatures during deformation (Sec. 2).

These include 1) the length of $\mathbf{b}=[001]$ dislocations in screw sense compared to other

orientations (\% $\mathbf{b}=[001]$ screw sense, lower at higher temperature $), 2)$ the relative

number of $\mathbf{b}=[100]$ dislocations (higher at higher temperature), and 3) the presence of

jogged dislocations (more prevalent at higher temperature) and kink bands (those with [100] slip are active at higher temperature-- Carter et al., 1968; Green and Radcliffe, 1972a, b; Boland and Buiskool Toxopeus, 1977).

Fig. 6 shows for all meteorites studied the $\% \mathbf{b}=[001]$ screw sense and the relative number of $\mathbf{b}=[100]$ dislocations. Both parameters suggest elevated temperature during deformation for Morrow County and Kernouvé (Fig. 6). Based on the $\mathbf{b}=[100]$ data, MIL 99301 and Park were probably deformed at somewhat elevated temperature (Fig. 6), consistent with the presence in these meteorites of jogged dislocations and kink bands (Table 1). In MIL 99301, at least one well-studied kink band (Fig. 4h, i) seems to be of the type activated at high temperature. At relatively low laboratory strain rates $\left(\sim 10^{-2}\right.$ to $\left.10^{-8} \mathrm{~s}^{-1}\right), \mathbf{b}=[100]$ dislocations begin to appear above $800{ }^{\circ} \mathrm{C}$ and become prevalent above $1000^{\circ} \mathrm{C}$ (Green, 1976; Gueguen and Nicolas, 1980). These transition temperatures increase at the higher strain rates that are expected for shock (Raleigh, 1968; Carter et al., 1968; Green, 1976; Gueguen and Nicolas, 1980). In none of the 


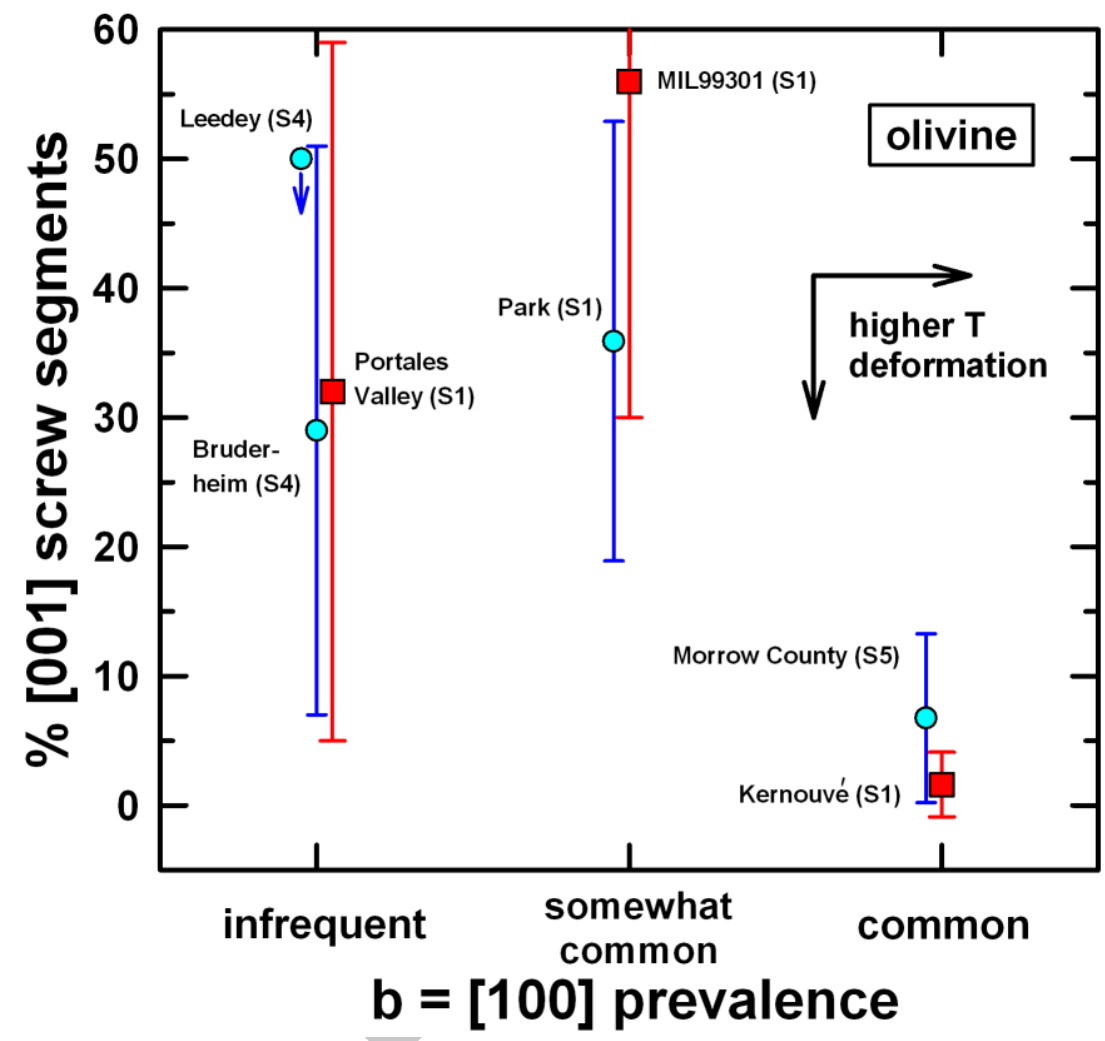

samples studied here are $\mathbf{b}=[100]$ dislocations prevalent. This suggests that those meteorites that contain moderately common (Park, MIL 99301) to common $\mathbf{b}=[100]$ dislocations (Kernouvé, Morrow County) were deformed at a temperature of $\geq 800-1000$ ${ }^{\circ} \mathrm{C}$, probably warmer for Kernouvé and Morrow County than for Park and MIL 99301.
Fig. 6. Relationship between two different proxies for deformation temperature in olivine, including $\mathbf{b}=[100]$ dislocation prevalence, and the percentage of $\mathbf{b}=[001]$ dislocations present in a screw orientation. For the latter, points show the mean values among TEM areas examined (excluding one atypical area in Morrow County) and the error bars show the standard deviation of these values. Symbols as in Fig. 5 .

[color in web, b/w in print]
For Morrow County, elevated deformation temperature is almost certainly the result of intense shock, consistent with evidence for some dynamic heating (Sec. 4.1). Assuming the applicability of shock loading experiments (Schmitt, 2000), and a best estimate for shock stage S5 of 35-45 GPa (Stöffler et al., 1991), a temperature increase of $\sim 700-900{ }^{\circ} \mathrm{C}$ can be inferred for shock stage S5. This is similar to the $\geq 800-1000{ }^{\circ} \mathrm{C}$ temperature implied for Morrow County based on $\mathbf{b}=[100]$ dislocations. 
For Kernouvé, Park, and MIL 99301, strong heating during intense shock is not viable, and shock deformation must instead have occurred when the parent bodies were hot at the time of impact deformation. Inferred temperatures of $\geq 800-1000{ }^{\circ} \mathrm{C}$ based on dislocation microstructure are similar to the peak metamorphic temperatures experienced by chondrites during thermal metamorphism (e.g., Huss et al., 2006).

Thus, deformation for Kernouvé (H6), Park (L6), and MIL 99301 (LL6) probably occurred during thermal metamorphism when the parent bodies were being metamorphosed to type 6 grade. This conclusion holds for three different parent bodies $(\mathrm{H}, \mathrm{L}, \mathrm{LL})$ among the three studied, suggesting a not uncommon process of impact into warm asteroidal bodies.

Shock deformation of an already warm target was suggested also for the Kobe CK4 chondrite based on the presence of extensive silicate darkening caused by small metal-sulfide inclusions in silicate such as olivine (Tomoeka et al., 2001). Such inclusions can form by shock injection of metallic melts into fractures (Leroux et al., 1996), and injection is enhanced when the target materials are warm (Schmitt, 2000; Nakamura et al., 2000). Limited silicate darkening is seen in both MIL 99301 and Portales Valley (Rubin et al., 2001; Rubin, 2002, 2004). This weakly supports the idea of impacting a warm target.

Also characteristic of shock deformation in a warm chondritic target is recrystallized troilite (Schmitt, 2000). If the pre-shock temperature is elevated (i.e., $\sim 650$ ${ }^{\circ} \mathrm{C}$ ), troilite recrystallizes readily during shock to form polycrystalline troilite even under conditions that result in little deformation of olivine and plagioclase (Schmitt, 2000). Polycrystalline troilite is not prevalent in any of the $\mathrm{S} 1$ chondrites but has been reported 
390 for MIL 99301 (Rubin, 2002, 2004). The dearth of polycrystalline troilite provides little

391 support for a warm target, but such troilite would not form if it had melted (Schmitt,

392 2000). This might be expected either for higher pre-shock temperatures or high

393 temperatures associated with stronger shock. In Portales Valley at least, troilite was

394 probably impact-melted along with metal (Ruzicka et al., 2005). Thus, the significance of

395 not finding much polycrystalline troilite in the annealed chondrites is not clear.

4.4. limplications for collisional events affecting ordinary chondrite parent bodies

Fig. 7 summarizes for olivine in all chondrites studied the amount of postdeformation annealing based on the FFB ratio, and temperature during shock based on the prevalence of $\mathbf{b}=[100]$ dislocations. This diagram can be used as a guide to understand the impact histories of the chondrites and their parent bodies. ratios imply rapid cooling following deformation and shallow burial beneath a cooling surface (Fig. 7; Sec. 4.1). All could have originated as ejecta of some sort. ${ }^{39} \mathrm{Ar}-{ }^{40} \mathrm{Ar}$ ages of $~ 500$ Ma for Bruderheim (Turner, 1969; Bogard et al., 1987) and $450-470 \mathrm{Ma}$ 405 for Morrow County (Patricia Clay, University of Manchester, pers. comm.) are consistent 406 with the postulated break-up event of the L chondrite parent body, and both meteorites

407 could have cooled in one or more of the break-up fragments. ${ }^{39} \mathrm{Ar}-{ }^{40} \mathrm{Ar}$ data for Leedey 408 imply an older reheating event and collision at $3.8 \mathrm{Ga}$ (Bogard et al., 1987), suggesting 409 Leedey cooled in near-surface regolith $\sim 3.8 \mathrm{Ga}$ ago and was not strongly shocked in the $410 \sim 0.5 \mathrm{Ga}$ event. Park has an unusually low shock stage for an $\mathrm{L}$ chondrite, with no 411 evidence it ever was significantly shocked. Still, it shows evidence for weak shock 412 occurring at an elevated temperature, while the parent body was warm (Sec. 4.3), 
413 followed by minimal post-shock annealing (Fig. 7). Park has an ancient ${ }^{39} \mathrm{Ar}-{ }^{40} \mathrm{Ar}$ plateau 414 age of $4492.6 \pm 9.5 \mathrm{Ma}$ (Patricia Clay, University of Machester, pers. comm.). The 415 microstructure and age data for Park are consistent with syn-metamorphic impact 416 excavation of warm interior materials from the parent body, and emplacement of these 417 materials near the surface of the parent body where cooling was rapid. Kernouvé olivine has both common $\mathbf{b}=[100]$ dislocations and low FFB ratios, 419 suggesting shock near peak metamorphic temperature followed by slow cooling at 420 depth (Fig. 7; Sec. 4.1, 4.3). The meteorite has an ancient ${ }^{39} \mathrm{Ar}-{ }^{40} \mathrm{Ar}$ age of $\sim 4.46 \mathrm{Ga}$ 421 (Turner et al., 1978), consistent with early cooling. Kernouvé was never significantly 422 shocked (Sec. 4.2), so it probably was minimally disturbed during metamorphism and 423 could have cooled slowly as warm sub-regolith (basement) material in the $\mathrm{H}$ chondrite 424 parent body. Still, the meteorite shows evidence for a weak shock occurring at high 425 ambient temperatures. Coarse metal veins in Kernouvé have been interpreted as a 426 manifestation of an early shock disturbance (Hutson, 1989; Rubin, 2003; Friedrich et al., 427 2013), which probably occurred in the same event that weakly deformed olivine at high 428 temperatures. Evidently, only a weak (S1) shock at high temperatures was needed to 429 mobilize metal into veins. 


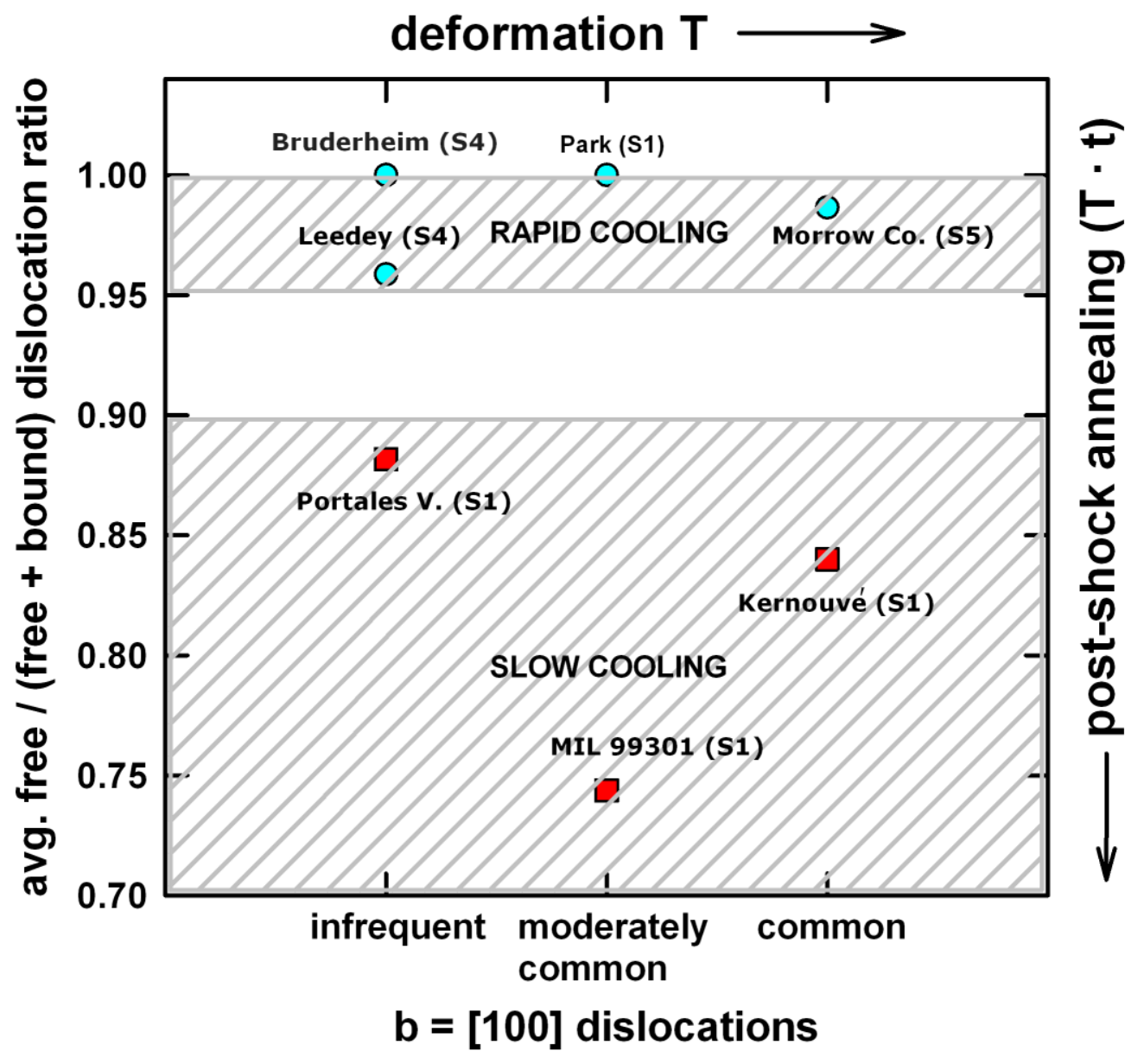

Fig. 7. Diagram summarizing thermal and deformation histories of meteorites as inferred from TEM data for olivine. Post-shock annealing is related to the value of average free/(free+bound) dislocation ratio and should correspond to cooling rate, whereas temperature during deformation is related to the prevalence of $b=[100]$ dislocations. There is no simple correspondence between post-shock annealing and deformation temperature. All the reference L 6 chondrites (circles) can be explained by rapid cooling following shock, whereas the annealed chondrites (squares) can be explained by deeper burial from a cooling surface. As discussed in the text, elevated temperatures during deformation can be explained by either intense shock metamorphism (for Morrow County) or warm target materials (for Kernouvé, MIL 99301, Park).

[color in web, b/w in print]

As with Kernouvé, MIL 99301 was shocked at elevated temperature and cooled at depth (Fig. 7; Sec. 4.1, 4.3). However, ${ }^{39} \mathrm{Ar}-{ }^{40} \mathrm{Ar}$ data for MIL 99301 suggest two shock events, one at $4.52 \pm 0.08 \mathrm{Ga}$ and another at $4.23 \pm 0.03 \mathrm{Ga}$ (Dixon et al., 2004). Although Dixon et al. suggested slow cooling for MIL 99301 in the second event, this 
437

438

439

440

441

442

443

444

445

446

447

448

449

450

451

452

453

454

455

456

457

458

459

seems unlikely. MIL 99301 has a wide range of shock stages including a small admixture of more highly shocked material (Fig. 1), possibly caused by impact mixing or heterogeneity introduced during a shock event. The first possibility is favored by a comparatively narrow range of shock effects seen in other chondrites such as Leedey, Bruderheim, and Morrow County (Fig. 1), which suggests that single shock events do not produce an overly large range of shock stages. In any case, given the evidence for strain obliteration in olivine during extended annealing of the sort that affected much of MIL 99301 (Sec. 4.2), it seems unlikely that olivine with highly different shock stages would be preserved during such annealing. Slow cooling more likely occurred before the introduction of highly shocked grains. Thus, the first degassing event $\sim 4.52 \mathrm{Ga}$ ago could have entailed slow cooling, while the parent body was undergoing thermal metamorphism, and a second shock event at $\sim 4.23 \mathrm{Ga}$ ago could have either excavated and mixed materials of diverse deformation and thermal histories or created heterogeneous shock effects.

Portales Valley also cooled slowly at depth (Fig. 7). Like Kernouvé, the meteorite contains coarse metal veins that probably formed by impact mobilization of metal (Kring et al., 1999; Rubin, 2003; Ruzicka et al., 2005). Unlike Kernouvé, Portales Valley could have been strongly shocked before extensive annealing (Sec. 4.2), consistent with formation directly below an impact crater (Kring et al., 1999; Rubin, 2003; Ruzicka et al., 2005) in well-insulated $\mathrm{H}$-chondrite basement. The Portales Valley source region could have been hot (possibly $\sim 900-950^{\circ} \mathrm{C}$ ) during impact (Ruzicka et al., 2005), but at face value a relatively low proportion of $\mathbf{b}=[100]$ dislocations in olivine suggests a lower deformation temperature (Fig. 7). However, microstructure data do not exclude the 
460 possibility of Portales Valley having been slightly cooler but still warm $\left(T<800^{\circ} \mathrm{C}\right)$ at the

461 time of impact, and many $\mathbf{b}=[100]$ dislocations may have been destroyed during

462 annealing, leading to an erroneously low estimate of deformation temperature. The

463 latter possibility is supported by the presence in Portales Valley of $\mathbf{b}=[101]$ dislocations

464 in well-formed subgrain boundaries that were likely produced by the combination of

$465 \mathbf{b}=[001]$ and $\mathbf{b}=[100]$ dislocations during dislocation climb (Sec. 3.2.5). Thus, Portales

466 Valley may indeed have been shocked while the parent body was warm and undergoing

467 thermal metamorphism, although the temperature at the time of impact is uncertain. An

468 old ${ }^{39} \mathrm{Ar}^{40} \mathrm{Ar}$ age for Portales Valley of $4477 \pm 16 \mathrm{Ma}$ (Garrison and Bogard, 2001)--

469 indistinguishable from Kernouvé and the older age for MIL 99301 -- is consistent with

470 early shock. Thus, it is possible that all of the slowly-cooled S1 meteorites (Kernouvé,

471 MIL 99301, Portales Valley) were deformed and annealed at depth in parent bodies that

472 were undergoing early thermal metamorphism.

473 4.5. Breaking paradigms

474

The traditional view of chondrite formation is that 1) "secondary" thermal

475 metamorphism pre-dated "tertiary" shock processes, and that 2) thermal metamorphism

476 caused by endogenic heating resulted in an onion-shell stratigraphy, with higher

477 metamorphic grades at greater depths (Dodd, 1981; Hutchison, 2004). However, each

478 of these paradigms may not be entirely valid. Our data support the idea that thermal

479 metamorphism and shock likely overlapped in time during and shortly after the accretion

480 of the H, L, and LL chondrite parent bodies (Grimm, 1985; Ganguly et al., 2013;

481 Friedrich et al., 2013, 2014; Swindle et al., 2014). Moreover, impact cratering occurring

482 concurrently with endogenic metamorphism could have redistributed material from 
483 different depths in the parent bodies, locally excavating hot and burying cold material.

484 An onion shell structure would tend to be reconfigured by impacts, destroying an

485 expected inverse correlation between cooling rate and metamorphic grade (Scott et al.,

486 2014), and possibly including an extensive scrambling caused by collisional disruption

487 and reaccretion (Grimm, 1985; Taylor et al., 1987; Ganguly et al., 2013). However, the

488 structure could be reformed during continued endogenic heating. This would lead to a 489 complex parent body stratigraphy that was non-axisymmetric and temporally variable.

490 Furthermore, our results indicate pitfalls in using the shock stage of olivine alone as a

491 guide to whether chondrites were significantly affected by shock. Some shock stage S1

492 chondrites (e.g., Portales Valley) were significantly shocked prior to thermal annealing

493 that partly obliterated strain effects in olivine. Thus, it might not be straightforward to use

494 the properties of chondrites to reconstruct simple thermal models of their asteroidal

495 parent bodies. Olivine microstructures investigated with transmission electron

496 microscopy can provide additional key evidence to aid in such reconstructions.

\section{CONCLUSION}

Detailed optical and electron petrographic studies for olivine in various ordinary

chondrites provide a wealth of information related to collisional and metamorphic

500 processes. The L6 chondrites Park, Leedey, Bruderheim and Morrow County show the

501 effects of varying shock intensity and all could have cooled quickly in ejecta fragments.

502 In contrast, the S1 chondrites Kernouvé (H6), Portales Valley (H6/7), and MIL 99301

503 (LL6) all show good evidence for extensive recovery during protracted annealing that

504 lowered optical strain in olivine as a result of burial at depth, probably within warm

505 parent bodies. In addition, there is good evidence that some $\mathrm{S} 1$ chondrites from each of 
506 the three ordinary chondrite groups, including Kernouvé, MIL 99301, and Park, were

507 shocked at elevated temperature $\left(\geq 800-1000^{\circ} \mathrm{C}\right)$, while the parent bodies were

508 undergoing endogenic thermal metamorphism. Portales Valley may also have been

509 shocked while the parent body was warm. The data show the pitfalls in relying on

510 optical shock stage alone to infer an absence of shock and to construct cooling models

511 for parent bodies. For example, Park, although never shocked significantly, shows

512 evidence for an impact scrambling process that transported hot interior materials to a

513 cooling surface. On the other hand, Kernouvé, also never shocked significantly, is more

514 likely to have cooled in place at depth in the parent body and to provide a record of

515 original parent body thermal metamorphic structure. Finally, the data for L6 chondrites,

516 all evidently rapidly cooled following shock and lacking evidence for much olivine

517 recovery, suggest that impact heating alone was not solely responsible for thermal

518 metamorphic effects in these or other chondrites. Burial at depth inside warm, insulating

519 bodies was necessary to result in significant olivine recovery.

\section{ACKNOWLEDGMENTS}

522 Christian University), and Linda Welzenbach (U.S. National Museum) are thanked for

523 samples that made this study possible. Special thanks are extended to Drs. Patricia

524 Clay, Katherine Joy and Henner Busemann (University of Manchester) for Ar dating of

525 Park and Morrow County. Finally, Alan Rubin and Ed Scott are thanked for constructive 526 reviews, and Wolf Uwe Reimold is thanked for editorial handling. This work was

527 supported by NASA grant NNX10AH336 (PI AR, Co-I RH). 
Ashworth J.R. and Barber D.J. (1975) Electron petrography of shock-deformed olivine in stony meteorites. Earth Planet. Sci. Lett. 27, 43-50.

Ashworth J.R. and Barber D.J. (1977) Electron microscopy of some stony meteorites. Phil. Trans. R. Soc. Lond. A. 286, 493-506.

Ashworth J.R. and Mallinson L.G. (1985) Transmission electron microscopy of L-group chondrites, 2. Experimentally annealed Kyushu. Earth Planet. Sci. Lett. 73, 3340.

Blacic J.D. and Christie J.M. (1973) Dislocation substructure of experimentally deformed olivine. Contrib. Mineral. Petrol. 42, 141-146.

Bogard D., Hörz F. and Johnson P. (1987) Shock effects and argon loss in samples of the Leedey L6 chondrite experimentally shocked to 29-70 GPa pressures. Geochim. Cosmochim. Acta 51, 2035-2044.

Boland J.N. and Buiskool Tokopeus J.M.A. (1977) Dislocation deformation mechanisms in peridotite xenoliths in kimberlites. Contrib. Mineral. Petrol. 60, 17-30.

Carter N.L., Raleigh C.B. and DeCarli P.S. (1968) Deformation of olivine in stony meteorites. J. Geophys. Res. 73, 5439-5461.

Demouchy S., Tommasi A., Boffa Ballaran T. and Cordier P. (2013) Low strength of Earth's uppermost mantle inferred from tri-axial deformation experiments on dry olivine crystals. Phys. Earth Planet. Interiors 220, 37-49.

Dixon E.T., Bogard D.D., Garrison D.H. and Rubin A.E. (2004) ${ }^{39} \mathrm{Ar}-{ }^{40} \mathrm{Ar}$ evidence for early impact events on the LL parent body. Geochim. Cosmochim. Acta 68, 3779-3790. 
551

552

553

554

555

556

557

558

559

560

561

562

563

564

565

566

567

568

569

570

571

572

Dodd R.T. (1981) Meteorites—A petrologic-chemical synthesis. Cambridge University Press, Cambridge.

Druiventak A., Trepmann C. A., Renner J., and Hanke K. (2011) Low-temperature plasticity of olivine during high stress deformation of peridotite at lithospheric conditions - An experimental study. Earth Planet. Sci. Lett. 311, 199-211.

Friedrich J.M., Ruzicka A., Rivers M.L., Ebel D.S., Thostenson J.O. and Rudolph R.A. (2013) Metal veins in the Kernouvé (H6 S1) chondrite: Evidence for pre- or synmetamorphic shear deformation. Geochim. Cosmochim. Acta 116, 71-83.

Friedrich J. M., Rubin A.E., Beard S.P., Swindle T.D., Isachsen C.E., Rivers M.L. and Macke R.J. (2014) Ancient porosity preserved in ordinary chondrites: Examining shock and compaction on young asteroids. Meteorit. Planet. Sci. 49, 1214-1231.

Gaboriaud R.J., Darot M., Gueguen Y. and Woirgard J. (1981) Dislocations in olivine indented at low temperatures. Phys. Chem. Minerals 7, 100-104.

Ganguly, J., Tirone M., Chakraborty S. and Domanik K. (2013) H-chondrite parent asteroid: A multistage cooling, fragmentation, and re-accretion history constrained by thermometric studies, diffusion kinetic modeling and geochronological data. Geochim. Cosmochim. Acta 105, 206-220.

Garrison D. H. and Bogard D.D. (2001) ${ }^{39} \mathrm{Ar}-{ }^{40} \mathrm{Ar}$ and space exposure ages of the unique Portales Valley H chondrite. Lunar Planet. Sci. XXXII. Lunar Planet. Sci. Inst., Houston. \#1137 (abstr.)

Goetze C. and Kohlstedt D.L. (1973) Laboratory study of dislocation climb and diffusion in olivine. J. Geophys. Res. 78, 5961-5971. 
573 Green H.W., II (1976) Plasticity of olivine in peridotites. In Electron Microscopy in

574 Mineralogy (ed. H.-R. Wenk). Springer-Verlag, Berlin. Ch. 6.6, pp. 443-464.

575 Green H.W., II and Radcliffe S.V. (1972a) Deformation processes in the upper mantle.

$576 \quad$ In Flow and Fracture of Rocks. Geophys. Monogr. 16, pp. 139-156.

577 Green H.W., II and Radcliffe S.V. (1972b) Dislocation mechanisms in olivine and flow in

578 the upper mantle. Earth Planet. Sci. Lett. 15, 239-247.

579 Greenwood R.C., Schmitz B., Bridges J.C., Hutchison R. and Franchi I.A. (2007)

580 Disruption of the L chondrite parent body: New oxygen isotope evidence from

581 Ordovician relict chromite grains. Earth Planet. Sci. Lett. 262, 204-213.

582 Grimm R.E. (1985) Penecontemporaneous metamorphism, fragmentation, and reassembly of ordinary chondrite parent bodies. J. Geophys. Res. 90, 2022-

584 2028.

585

586

587

588

589

590

591

592

593

594

Gueguen Y. and Nicolas A. (1980) Deformation of mantle rocks. Ann. Rev. Earth Planet. Sci. 8, 119-144.

Haack H., Farinella P., Scott E.R.D. and Keil K.(1996) Meteoritic, asteroidal, and theoretical constraints on the $500 \mathrm{Ma}$ disruption of the $\mathrm{L}$ chondrite parent body. Icarus 119, 182-191.

Huss G.R., Rubin A.E. and Grossman J.N. (2006) Thermal metamorphism in chondrites. In Meteorites and the Early Solar System II (eds. D.S. Lauretta and H.Y. McSween Jr.). University of Arizona Press, Tucson. pp. 567-586.

Hutchison R. (2004) Meteorites-A petrologic, chemical and isotopic synthesis. Cambridge University Press, Cambridge. 
595

596

597

598

599

600

601

602

603

604

605

606

607

608

609

610

611

612

613

614

615

616

617

Hutson M.L. (1989) Shock effects in H-group chondrites. Lunar Planet. Sci. XX. Lunar Planet. Sci. Inst., Houston, p. 436.

Hutson M., Hugo R., Ruzicka A., and Killgore M. (2007) Annealing after shock:

Evidence from olivine microstructures in Portales Valley. Meteorit. Planet. Sci.

42. \#5072 (abstr.).

Hutson M.L., Hugo R., Ruzicka A.M. and Rubin A. E. (2009) Olivine microstructures in the Miller Range 99301 (LL6) ordinary chondrite. Lunar Planet Sci. XXXX. Lunar Planet. Inst., Houston. \#1081 (abstr.).

Jamsja N. and Ruzicka A. (2010) Shock and thermal history of NWA 4859, an annealed impact-melt breccia of LL-chondrite parentage containing unusual igneous features and pentlandite. Meteorit. Planet. Sci. 45, 828-849.

Joreau P., Leroux H. and Doukhan J.-C. (1996) A transmission electron microscopy (TEM) investigation of opaque phases in shocked chondrites. Meteorit. Planet.

Sci. 31, 305-312.

Joreau P., Leroux H. and Doukhan J.-C. (1997) A transmission electron microscope investigation of shock metamorphism in olivine of the llafegh 013 chondrite. Meteorit. Planet. Sci. 32, 309-316.

Kleine T., Touboul M., Van Orman J.A., Bourdon B., Maden C., Metzger K., and Halliday A. (2008) Hf-W thermochronometry: Closure temperature and constraints on the accretion and cooling history of the $\mathrm{H}$ chondrite parent body. Earth Planet. Sci. Lett. 270, 106-118.

Kring D.A., Hill D.H., Gleason J.D., Britt D.T., Consolmagno G.J., Farmer M., Wilson S. and Haag R. (1999) Portales Valley: A meteoritic sample of the brecciated and 
metal-veined floor of an impact crater on an $\mathrm{H}$ chondrite asteroid. Meteorit. Planet. Sci. 34, 663-669.

Langenhorst F., Joreau P. and Doukhan J.-C. (1995) Thermal and shock metamorphism of the Tenham chondrite: A TEM examination. Geochim. Cosmochim. Acta 59, 1835-1845.

Leroux H. (2001) Microstructural signatures of major minerals in meteorites. Eur. J. Mineral. 13, 253-272.

Leroux H., Doukhan J.-C. and Guyot F. (1996) An analytical electron microscopy (AEM) investigation of opaque inclusions in some type 6 ordinary chondrites. Meteorit. Planet. Sci. 31, 767-776.

Madon M. and Poirier J.P. (1983) Transmission electron microscope observations of $\alpha$, $ß$ and $\mathrm{y}(\mathrm{Mg}, \mathrm{Fe})_{2} \mathrm{SiO}_{4}$ in shocked meteorites: planar defects and polymorphic transitions. Phys. Earth Planet. Interiors 33, 31-44.

Nakamura T., Tomeoka K., Takaoka N., Sekine T. and Takeda H. (2000) Impactinduced textural changes of CV carbonaceous chondrites: Experimental reproduction. Icarus 146, 289-300.

Phakey P., Dollinger G. and Christie J. (1972) Transmission electron microscopy of experimentally deformed olivine crystals. In Flow and Fracture of Rocks, Geophys. Monogr. 16, pp.139-156.

Raleigh C.B. (1968) Mechanisms of plastic deformation of olivine. J. Geophys. Res. 73, 5391-5406. 
Rubin A.E. (1992) A shock metamorphic model for silicate darkening and compositionally variable plagioclase in CK and ordinary chondrites. Geochim. Cosmochim. Acta 56, 1705-1714.

Rubin A.E. (1994) Metallic copper in ordinary chondrites. Meteoritics 29, 93-98.

Rubin A.E. (1995) Petrologic evidence for collisional heating of chondritic asteroids. Icarus 113, 156-167.

Rubin A.E. (2002) Post-shock annealing of Miller Range 99301 (LL6): Implications for impact heating of ordinary chondrites. Geochim. Cosmochim. Acta 66, 33273337.

Rubin A.E. (2003) Chromite-plagioclase assemblages as a new shock indicator: implications for the shock and thermal histories of ordinary chondrites. Geochim. Cosmochim. Acta 67, 2695-2709.

Rubin A.E. (2004) Postshock annealing and postannealing shock in equilibrated ordinary chondrites: Implications for the thermal and shock histories of chondritic asteroids. Geochim. Cosmochim. Acta 68, 673-689.

Rubin A. E., Ulff-Møller F., Wasson J.T. and Carlson W.D. (2001) The Portales Valley meteorite breccia: Evidence for impact induced melting and metamorphism of an ordinary chondrite. Geochim. Cosmochim. Acta 66, 323-342

Ruzicka A. (1990) Deformation and thermal histories of chondrules in the Chainpur (LL3.4) chondrite. Meteoritics 25, 101-113.

Ruzicka A. and Hugo R. (2011) A shocking tale: TEM observations of deformed olivine in ordinary chondrites. Meteorit. Planet. Sci. 46, \#5368 (abstr.). 
661

662

663

664

665

666

667

668

669

670

671

672

673

674

675

676

677

678

679

680

681

682

Ruzicka A. and Hugo R. (2014) Microstructures in olivine from ordinary chondrites:

Evidence for post-shock thermal annealing and syn-metamorphic shock. Lunar Planet. Sci. XXXXV. Lunar. Planet. Sci. Inst., Houston. \#1306 (abstr.).

Ruzicka, A., Killgore M., Mittlefehldt D.W. and Fries M.D. (2005) Portales Valley:

Petrology of a metallic-melt meteorite breccia. Meteorit. Planet. Sci. 40, 261-295.

Schmitz B., Tassinari M. and Peucker-Ehrenbrink B. (2001) A rain of ordinary chondritic meteorites in the early Ordovician. Earth Planet. Sci. Lett. 194, 1-15.

Scott E.R.D and Rajan R.S. (1981) Metallic minerals, thermal histories and parent bodies of some xeonolithic, ordinary chondrite meteorites. Geochim. Cosmochim. Acta 45, 53-67.

Scott E.R.D., Taylor G.J., Newsom H.E., Herbert F., Zolensky M. and Kerridge J.F. (1989) Chemical, thermal and impact processing of asteroids. In Asteroids II (eds. R.P. Binzel, T. Gehrels, M. S. Matthews). Univ. Arizona Press, Tucson. pp. 701-739.

Scott E.R.D., Krot T.V., Goldstein J.I. and Wakita S. (2014) Thermal and impact history of the $\mathrm{H}$ chondrite parent asteroid during metamorphism: Constraints from metallic Fe-Ni. Geochim. Cosmochim. Acta 136, 13-27.

Sharp T.G. and P.S. DeCarli (2006) Shock effects in meteorites. In Meteorites and the Early Solar System II (eds. D.S. Lauretta, H.Y. McSween, Jr.). Univ, Arizona Press, Tucson. pp. 653-677.

Schmitt R.T. (2000) Shock experiments with the H6 chondrite Kernouvé: Pressure calibration of microscopic shock effects. Meteorit. Planet. Sci. 35, 545-560. 
683 684 685 686 687 688 689 690 691

692

693 694 695 696 697 698 699 700 701 702 703

Schmitt R.T. and Stöffler D. (1995) Experimental data in support of the 1991 shock classification of chondrites. Meteoritics 30, 574-575.

Sears D.W., Ashworth J.R., Broadbent C.P. and Bevan A.W.R. (1984) Studies of an artificially shock-loaded H-group chondrite. Geochim. Cosmochim. Acta 48, 343360.

Spray J.G. (2010) Frictional melting processes in planetary materials: From hypervelocity impact to earthquakes. Annu. Rev. Earth Planet. Sci. 38, 221-254.

Stöffler D., Bischoff A., Buchwald V. and Rubin A.E. (1988) Shock effects in meteorites. In Meteorites and the Early Solar System (eds. J. F. Kerridge, M. S. Matthews). Univ. Arizona Press, Tucson. pp. 165- 202.

Stöffler D., Keil K. and Scott E.R.D. (1991) Shock metamorphism in ordinary chondrites. Geochim. Cosmochim. Acta 55, 3845-3867.

Swindle T. D., Kring D.A. and Weirich J.R. (2014) ${ }^{40} \mathrm{Ar} /{ }^{39} \mathrm{Ar}$ ages of impacts involving ordinary chondrite meteorites. Geological Society, London, Special Publications 378, 333-347.

Tait A.W., Tomkins A.G., Godel B.M., Wilson S.A. and Hasalova P. (2014) Investigation of the H7 ordinary chondrite, Watson 012 : Implications for recognition and classification of Type 7 meteorites. Geochim. Cosmochim. Acta 134, 175-196.

Taylor G.J., Maggiore P., Scott E.R.D., Rubin A.E. and Keil K. (1987) Original structures and fragmentation and reassembly histories of asteroids: Evidence from meteorites. Icarus 69, 1-13. 
704 Tomeoka K., Ohnishi I. and Nakamura N. (2001) Silicate darkening in the Kobe CK 705 chondrite: Evidence for shock metamorphism at high temperatures. Meteorit. Planet. Sci. 36, 1535-1545.

707 Töpel-Schadt J. and Müller W.F. (1985) The submicroscopic structure of the unequilibrated ordinary chondrites Chainpur, Mezö-Madaras and Tieschitz: a transmission electron microscopic study. Earth Planet. Sci. Lett. 74, 1-12.

710 Trieloff M., Jessberger E.K., Herrwerth I., Hopp J., Fiéni C., Ghélis M., Bourot-Denise M. and Pellas P. (2003) Structure and thermal history of the $\mathrm{H}$-chondrite parent asteroid revealed by thermochronometry. Nature 422, 502-506.

713 Turner G. (1969) Thermal histories of meteorites by the ${ }^{39} \mathrm{Ar}-{ }^{40} \mathrm{Ar}$ method. In Meteorite Research (ed. P. Millman), Springer Netherlands. pp. 407-417.

715 Turner G., Enright M.C. and Cadogan P.H. (1978) The early history of chondrite parent bodies inferred from ${ }^{40} \mathrm{Ar}^{39} \mathrm{Ar}$ ages. Proc. Lunar Planet. Sci. Conf. 9th, 989-1025. 


\section{ELECTRONIC ANNEX}

Includes: Table EA-1, Table EA-2, Fig. EA-1

For the paper "Deformation and thermal histories of ordinary chondrites:

Evidence for post-deformation annealing and syn-metamorphic shock" 
Table EA-1. Olivine shock stage data based on optical microscopy; meteorites are arranged according to increasing weighted shock stage. ${ }^{a}$

\begin{tabular}{|c|c|c|c|c|c|c|c|c|c|c|c|}
\hline Meteorite & Sections $^{\mathrm{b}}$ & $\begin{array}{c}\text { Number } \\
\text { of } \\
\text { grains }\end{array}$ & $\%$ S1 & $\%$ S2 & $\%$ S3 & $\%$ S4 & $\%$ S5 & $\%$ S6 & $\begin{array}{l}\text { Conventional } \\
\text { shock stage }\end{array}$ & $\begin{array}{l}\text { Weighted } \\
\text { shock } \\
\text { stage }\end{array}$ & Comment \\
\hline Kernouvé & $\begin{array}{l}0666-1, \\
0666-2 A, \\
\text { USNM } \\
1054-2\end{array}$ & 115 & 91.3 & 7.0 & 0 & 0 & 0 & 0.9 & S1 & S1.13 & $\begin{array}{l}\text { Irregular } \\
\text { metal veins; } \\
\text { low angle } \\
\text { boundaries. }\end{array}$ \\
\hline $\begin{array}{l}\text { Portales } \\
\text { Valley }\end{array}$ & $\begin{array}{l}0056-3 \\
0056-4\end{array}$ & 100 & 84 & 16 & 0 & 0 & 0 & 0 & & S1.16 & $\begin{array}{l}\text { Metal veins; } \\
\text { low angle }\end{array}$ \\
\hline Park & $\begin{array}{l}0617-1 A, \\
0617-1 B, \\
0617-2 A\end{array}$ & 153 & 76.5 & 15.0 & 6.5 & 1.3 & 0 & 0 & S1 & S1.35 & $\begin{array}{l}\text { Low angle } \\
\text { boundaries. }\end{array}$ \\
\hline MIL 99301 & $\begin{array}{l}\text { 0422-1, } \\
0422-B\end{array}$ & 65 & 73.8 & 13.8 & 1.5 & 4.6 & 1.5 & 4.6 & S1 & S1.60 & $\begin{array}{l}\text { Breccia; low } \\
\text { angle } \\
\text { boundaries. }\end{array}$ \\
\hline Holbrook & $\begin{array}{l}0302-5 B \\
0302-6 A\end{array}$ & 94 & 30.9 & 18.1 & 26.6 & 24.5 & 0 & 0 & S3 & S2.45 & $\begin{array}{l}\text { Breccia; not } \\
\text { used for } \\
\text { TEM owing } \\
\text { to large } \\
\text { dispersion } \\
\text { of shock } \\
\text { stages. }\end{array}$ \\
\hline Bruderheim & $\begin{array}{l}0618-1 A, \\
0618-1 B, \\
0618-2 A\end{array}$ & 136 & 0 & 1.5 & 30.9 & 55.9 & 11.8 & 0 & S4 & S3.78 & $\begin{array}{l}\text { Minor melt } \\
\text { pockets. }\end{array}$ \\
\hline Leedey & $\begin{array}{l}\text { 0504-1A, } \\
0504-1 B \\
\text { ASU } \\
489-A-1\end{array}$ & 162 & 0 & 0.6 & & 72.2 & 11.1 & 0 & S4 & S3.94 & $\begin{array}{l}\text { Strong S4. } \\
\text { Minor melt } \\
\text { pockets. }\end{array}$ \\
\hline $\begin{array}{l}\text { Morrow } \\
\text { County }\end{array}$ & $\begin{array}{l}0497-2 A \\
0497-6 A, \\
0497-6 B\end{array}$ & 149 & 0 & 0 & 3.4 & 47.0 & 49.7 & 0 & S5 & S4.46 & $\begin{array}{l}\text { Maskelynite; } \\
\text { shock veins; } \\
\text { chr-plagc. }\end{array}$ \\
\hline
\end{tabular}


ACCEPTED MANUSCRIIPI

Table EA-2 (next three pages). Olivine microstructure data for individual areas examined with transmission electron microscopy.

\begin{tabular}{|c|c|c|c|c|c|c|}
\hline $\begin{array}{l}\text { Meteorite } \\
\text { / sections }^{\mathrm{a}}\end{array}$ & Area & Dislocation character & $\rho\left(\mathrm{cm}^{-2}\right)^{b}$ & Burgers vector $\mathbf{b}$ & $\% \mathrm{FFB}^{\mathrm{C}}$ & $\begin{array}{l}\%[001] \\
\text { screw }\end{array}$ \\
\hline \multirow{12}{*}{$\begin{array}{l}\text { Bruderheim } \\
\text { / 0618-1B }\end{array}$} & $1 \mathrm{~A} 10$ & [001] screws with straight edges, few [100] & $5.4 \mathrm{E}+09$ & & 100 & 51 \\
\hline & $1 \mathrm{~A} 11$ & long [001] screws with straight edges & $2.8 \mathrm{E}+09$ & & 100 & 66 \\
\hline & $1 \mathrm{~A} 12$ & long [001] screws with straight edges & $2.0 \mathrm{E}+09$ & & 100 & 32 \\
\hline & $1 \mathrm{~A} 13 \mathrm{C}$ & long [001] screws with straight edges & $2.4 \mathrm{E}+09$ & & 100 & 43 \\
\hline & $1 \mathrm{~A} 13 \mathrm{e}$ & long [001] screws with straight edges & $7.1 \mathrm{E}+09$ & & 100 & 58 \\
\hline & B3-ol & straight \& jogged [001] & $2.3 E+10$ & & 100 & 27 \\
\hline & $2 \mathrm{~A} 1$ & slightly curved \& jogged [001], few screws & $6.4 \mathrm{E}+10$ & & 100 & 4 \\
\hline & $2 \mathrm{~A} 2$ & slightly curved \& jogged [001], few screws & $8.0 \mathrm{E}+10$ & & 100 & 5 \\
\hline & $2 \mathrm{~A} 2 \mathrm{a}$ & slightly curved \& jogged [001], few screws & $1.5 \mathrm{E}+11$ & & 100 & 3 \\
\hline & $2 \mathrm{~F} 1$ & slightly curved \& jogged [001], some screws & $1.0 \mathrm{E}+10$ & & 100 & 9 \\
\hline & 2D1 & slightly curved \& jogged [001], some screws & $1.5 E+10$ & & 100 & 25 \\
\hline & $2 A 3$ & curved \& jogged [001], some screws, [100] & 1.6E+10 & [001], [100] & 100 & 20 \\
\hline \multirow{12}{*}{$\begin{array}{l}\text { Leedey } \\
\text { / 0504-1B }\end{array}$} & $4 \mathrm{~A} 2$ & long [001] screws, others, some curved & $5.53 E+09$ & & 100 & 12 \\
\hline & $4 \mathrm{~A} 3$ & long [001] screws, others, some curved & 1.98E+09 & [001] & 100 & 21 \\
\hline & $4 \mathrm{~A} 4$ & [001] screws \& bowed edges, curved [100] & $3.08 \mathrm{E}+09$ & [100], [001] & 93 & 46 \\
\hline & 4A5 & long [001] screws & $5.30 \mathrm{E}+09$ & [001] & 100 & 78 \\
\hline & 4B1 & long [001] screws, others, some curved & $1.02 E+10$ & & & \\
\hline & 4B3 & long [001] screws, others, some curved & $2.14 \mathrm{E}+10$ & & 100 & 39 \\
\hline & $4 \mathrm{C} 1$ & long [001] screws, others, some curved & $2.90 \mathrm{E}+09$ & [100], [001] & & \\
\hline & $4 \mathrm{C} 2$ & long [001] screws, arrays, kink bands & 7.05E+08 & & 70 & 73 \\
\hline & $4 \mathrm{E} 1$ & straight 3 vectors, many short curved & $8.16 \mathrm{E}+08$ & [001] & 100 & 36 \\
\hline & 4E2 & long [001] screws, others, some curved & $2.42 \mathrm{E}+09$ & & 100 & 72 \\
\hline & $4 \mathrm{~F} 1$ & long [001] screws, others, some curved & 2.07E+09 & & 100 & 55 \\
\hline & 4D2 & frequent kink bands & +2 & [001] & & \\
\hline \multirow{13}{*}{$\begin{array}{l}\text { Morrow County } \\
\text { / 0497-6B }\end{array}$} & $1 \mathrm{~A} 2$ & curved, loops, few straight segments & $1.37 E+09$ & & 100 & 18 \\
\hline & $1 \mathrm{~A} 4$ & curved, tangles & $1.21 E+10$ & [001] & 100 & 8 \\
\hline & $1 \mathrm{~A} 10$ & curved, loops, few straight segments & $2.40 \mathrm{E}+10$ & & 100 & 0 \\
\hline & 1B1 & curved, loops, few straight segments & 4.30E+09 & [001], [100] & 100 & 16 \\
\hline & 1B2 & curved, loops, few straight segments & $1.15 E+10$ & [001], [100], others? & 92 & \\
\hline & 1B3 & curved, loops, few straight segments & $3.91 E+09$ & & 93 & 9 \\
\hline & $1 \mathrm{~B} 6$ & curved, loops, few straight segments & 8.31E+09 & & 100 & 11 \\
\hline & $1 \mathrm{C1}$ & curved, loops & 9.99E+09 & {$[001],[100]$} & 100 & 0 \\
\hline & $2 \mathrm{~A} 1$ & curved, loops, few straight segments & $3.41 \mathrm{E}+09$ & {$[001],[100]$} & 100 & 5 \\
\hline & $2 \mathrm{~A} 2$ & curved, loops & 9.96E+09 & [001] & 100 & 6 \\
\hline & $2 \mathrm{~A} 4$ & curved, loops, some straight segments & $2.30 \mathrm{E}+08$ & [001] & 100 & 43 \\
\hline & FIB-1 & curved, loops & 4.13E+09 & [001] predominant, [100] & 100 & 0 \\
\hline & FIB-2 & curved, loops & $5.09 \mathrm{E}+09$ & [001] predominant, [100] & 100 & 0 \\
\hline \multirow{3}{*}{$\begin{array}{l}\text { Park } \\
\text { / 0617-1B }\end{array}$} & $2 \mathrm{~A} 2$ & curved, straight [001] screws & $1.39 \mathrm{E}+08$ & & 100 & 49 \\
\hline & $2 A 3$ & straight screws from kink band & 1.87E+07 & & 100 & 62 \\
\hline & 2B1 & 2 & $3.55 E+08$ & [001], [100] & 100 & 45 \\
\hline
\end{tabular}


ACCEPTED MANUSCRIPT

\begin{tabular}{|c|c|c|c|c|c|c|}
\hline Park continued & $\begin{array}{l}\text { 2B1a } \\
2 B 3 \\
2 B 4 \\
2 B 2 R \\
2 D 1-o l \\
2 G 1 \\
1 A 1 a \\
1 A 1 \\
1 A 2 \\
1 A 3 a 1 \\
1 A 3 a \\
1 A 3 b \\
1 A 3 c \\
1 A 4 \\
1 A 5\end{array}$ & $\begin{array}{c}\text { curved [001], straight [001] screws } \\
\text { curved, straight screws from kink band } \\
\text { curved, straight [001] screws } \\
\text { straight screws from kink band, small loops } \\
\text { array of short [100] segments } \\
\text { curved [001], few [001] screws, tangle } \\
\text { [001] with long screws and bowed edges } \\
\text { curved [001], straight [001] screws } \\
\text { curved, looped, long [001] from kink band } \\
\text { curved [001], straight [001] screws } \\
\text { curved [001], straight [001] screws } \\
\text { curved [001], straight [001] screws } \\
\text { curved [001], straight [001] screws } \\
\text { curved [001], straight [001] screws } \\
\text { curved [001], straight [001] screws }\end{array}$ & $\begin{array}{l}1.58 \mathrm{E}+08 \\
3.09 \mathrm{E}+08 \\
6.69 \mathrm{E}+08 \\
2.75 \mathrm{E}+08 \\
8.82 \mathrm{E}+07 \\
3.12 \mathrm{E}+07 \\
8.57 \mathrm{E}+08 \\
1.26 \mathrm{E}+09 \\
7.20 \mathrm{E}+08 \\
1.13 \mathrm{E}+09 \\
9.26 \mathrm{E}+08 \\
8.32 \mathrm{E}+08 \\
3.10 \mathrm{E}+08 \\
3.54 \mathrm{E}+08 \\
1.10 \mathrm{E}+09 \\
\end{array}$ & $\begin{array}{c}{[001]} \\
{[001],[100]} \\
{[100],[?]} \\
{[001],[100]}\end{array}$ & $\begin{array}{l}100 \\
100 \\
100 \\
100 \\
100 \\
100 \\
100 \\
100 \\
100 \\
100 \\
100 \\
100 \\
100 \\
100 \\
100 \\
\end{array}$ & $\begin{array}{c}60 \\
19 \\
17 \\
28 \\
28 \\
6 \\
60 \\
24 \\
32 \\
45 \\
18\end{array}$ \\
\hline $\begin{array}{l}\text { Kernouvé } \\
\text { / 0666-1 }\end{array}$ & $\begin{array}{l}\text { 4A1 } \\
4 \mathrm{~A} 2 \\
4 \mathrm{~A} 3 \\
4 \mathrm{~A} 4 \\
4 \mathrm{~A} 5 \\
4 \mathrm{~A} 6 \\
4 \mathrm{~A} 7 \\
4 \mathrm{~A} 8 \\
4 \mathrm{~A} 9 \\
4 \mathrm{~A} 10 \\
3 \mathrm{~A} 1 \\
3 \mathrm{~A} 2 \mathrm{a} \\
3 \mathrm{~A} 3 \mathrm{a} \\
3 \mathrm{~A} 3 \mathrm{~b} \\
3 \mathrm{~A} 3 \mathrm{c} \\
3 \mathrm{~A} 3 \mathrm{~d} \\
3 \mathrm{~A} 3 \mathrm{e} \\
3 \mathrm{~A} 3 \mathrm{f} \\
3 \mathrm{~A} 10 \\
3 \mathrm{~A} 10 \mathrm{a}\end{array}$ & $\begin{array}{c}\text { [001] well formed array, loose array of [100] } \\
\text { random bowed + } 2 \text { well-formed arrays } \\
\text { [001] screws, curved [001] in array } \\
\text { none } \\
\text { none } \\
\text { isolated } \\
\text { none } \\
\text { curved arrays ([100] and [001]) } \\
\text { [001] curved into a poorly formed array } \\
\text { well \& poorly formed intersecting arrays } \\
\text { none } \\
\text { loosely formed [001] \& [100] arrays } \\
\text { slightly curved, some intersections } \\
\text { slightly curved, very low density } \\
\text { slightly curved, some intersections } \\
\text { slightly curved very low density } \\
\text { none } \\
\text { slightly curved, loosely formed array } \\
\text { slightly curved \& intersecting, one array } \\
\text { straight, possibly pure edge }\end{array}$ & $\begin{array}{l}1.6 \mathrm{E}+08 \\
1.8 \mathrm{E}+08 \\
1.6 \mathrm{E}+08 \\
1.0 \mathrm{E}+00 \\
1.0 \mathrm{E}+00 \\
9.3 \mathrm{E}+07 \\
1.0 \mathrm{E}+00 \\
4.6 \mathrm{E}+08 \\
3.3 \mathrm{E}+08 \\
2.8 \mathrm{E}+08 \\
1.0 \mathrm{E}+00 \\
4.0 \mathrm{E}+08 \\
2.2 \mathrm{E}+08 \\
6.7 \mathrm{E}+06 \\
7.7 \mathrm{E}+07 \\
6.7 \mathrm{E}+06 \\
1.0 \mathrm{E}+00 \\
6.0 \mathrm{E}+07 \\
6.8 \mathrm{E}+08 \\
6.4 \mathrm{E}+07\end{array}$ & $\begin{array}{l}\text { mostly [001], some [100] } \\
\text { mostly [001], some [100] } \\
\text { [001] edge }\end{array}$ & $\begin{array}{c}42 \\
54 \\
79 \\
100 \\
\\
100 \\
\\
100 \\
100 \\
0 \\
\\
100 \\
100 \\
100 \\
100 \\
100 \\
\\
100 \\
74 \\
100 \\
\end{array}$ & $\begin{array}{l}0 \\
0 \\
0 \\
0 \\
0\end{array}$ \\
\hline $\begin{array}{l}\text { Portales Valley } \\
\text { / 0056-3, } \\
0056-4\end{array}$ & $\begin{array}{l}\mathrm{AA} \\
\mathrm{Ab} \\
\mathrm{Ac} \\
\mathrm{Ba} \\
\mathrm{E} \\
\mathrm{F} \\
\mathrm{Fb} \\
\mathrm{H} \\
\mathrm{Hh}\end{array}$ & $\begin{array}{c}\text { none } \\
\text { isolated \& curved } \\
\text { isolated } \\
\text { none } \\
\text { isolated \& curved, arrays } \\
\text { none } \\
\text { isolated } \\
\text { none } \\
\text { none }\end{array}$ & $\begin{array}{l}1.0 \mathrm{E}+00 \\
3.6 \mathrm{E}+08 \\
9.6 \mathrm{E}+07 \\
1.0 \mathrm{E}+00 \\
8.6 \mathrm{E}+08 \\
1.0 \mathrm{E}+00 \\
3.0 \mathrm{E}+06 \\
1.0 \mathrm{E}+00 \\
1.0 \mathrm{E}+00\end{array}$ & $\begin{array}{c}{[001]} \\
{[001], \text { some }[100] \text { and }[101]}\end{array}$ & $\begin{array}{l}100 \\
100 \\
12 \\
100\end{array}$ & 0 \\
\hline
\end{tabular}


ACCEPTED MANUSCRIPT

\begin{tabular}{|c|c|c|c|c|c|c|}
\hline $\begin{array}{l}\text { Portales Valley } \\
\text { continued }\end{array}$ & $\begin{array}{l}\mathrm{K} \\
\mathrm{Kb} \\
\mathrm{Kk} \\
\mathrm{Kl} \\
\mathrm{L} \\
\mathrm{Lb} \\
\mathrm{Lb} 2 \\
\mathrm{Lb3} \\
\mathrm{Mb} \\
\mathrm{Mc} \\
\mathrm{Md} \\
\mathrm{Me} \\
\mathrm{Na} \\
\mathrm{Nb} \\
\mathrm{Nc} \\
\mathrm{O} \\
\mathrm{Oa} \\
\mathrm{Ob} \\
\mathrm{Oc} \\
\mathrm{Od} \\
\mathrm{Oe} \\
\end{array}$ & $\begin{array}{c}\text { intersecting \& curved } \\
\text { isolated } \\
\text { intersecting \& curved } \\
\text { intersecting \& curved, parallel straight } \\
\text { parallel straight, intersecting \& curved } \\
\text { parallel straight, intersecting \& curved } \\
\text { parallel straight } \\
\text { parallel straight, intersecting \& curved } \\
\text { parallel straight, tangles } \\
\text { parallel straight, tangles } \\
\text { parallel straight } \\
\text { parallel straight, tangles, arrays } \\
\text { isolated \& curved } \\
\text { none } \\
\text { none } \\
\text { many } \\
\text { isolated \& curved, arrays } \\
\text { intersecting \& curved, tangles } \\
\text { isolated \& curved } \\
\text { intersecting \& curved, tangles, arrays } \\
\text { intersecting \& curved, tangles, arrays }\end{array}$ & $\begin{array}{l}5.5 \mathrm{E}+08 \\
1.1 \mathrm{E}+06 \\
4.5 \mathrm{E}+07 \\
1.8 \mathrm{E}+08 \\
2.8 \mathrm{E}+09 \\
2.9 \mathrm{E}+09 \\
3.5 \mathrm{E}+08 \\
2.5 \mathrm{E}+08 \\
8.3 \mathrm{E}+09 \\
2.5 \mathrm{E}+09 \\
1.4 \mathrm{E}+10 \\
1.9 \mathrm{E}+09 \\
7.3 \mathrm{E}+07 \\
1.0 \mathrm{E}+00 \\
1.0 \mathrm{E}+00 \\
1.2 \mathrm{E}+10 \\
2.6 \mathrm{E}+08 \\
1.8 \mathrm{E}+08 \\
1.1 \mathrm{E}+09 \\
2.1 \mathrm{E}+09 \\
1.5 \mathrm{E}+09 \\
\end{array}$ & [001] screws & $\begin{array}{c}100 \\
100 \\
100 \\
100 \\
100 \\
100 \\
100 \\
96 \\
100 \\
100 \\
100 \\
82 \\
100 \\
\\
\\
\\
43 \\
100 \\
13 \\
95 \\
100 \\
\end{array}$ & $\begin{array}{c}0 \\
67 \\
68 \\
52 \\
71 \\
64 \\
51 \\
\\
30 \\
16\end{array}$ \\
\hline $\begin{array}{l}\text { MIL } 99301 \\
\text { / 0422-B }\end{array}$ & $\begin{array}{l}\mathrm{F} 3 \\
\mathrm{~F} 4 \\
\mathrm{G} 1 \\
\mathrm{G} 1 \mathrm{a} \\
\mathrm{G} 1 \mathrm{~b} \\
\mathrm{G} 5 \mathrm{a} \\
\mathrm{G} 6 \mathrm{a} \\
\mathrm{G} 6 \mathrm{~b} \\
\mathrm{G} 7\end{array}$ & $\begin{array}{c}\text { straight [001] screws } \\
\text { free curved; straight on array } \\
\text { kink band with jogged } 001 \text { screws } \\
\text { jogged cutting through } 001 \text { screws } \\
\text { straight, curved, arrays }\end{array}$ & $\begin{array}{l}1.4 \mathrm{E}+09 \\
1.0 \mathrm{E}+00 \\
3.9 \mathrm{E}+07 \\
3.0 \mathrm{E}+08 \\
8.7 \mathrm{E}+07 \\
1.8 \mathrm{E}+08 \\
1.0 \mathrm{E}+08 \\
6.3 \mathrm{E}+07 \\
6.0 \mathrm{E}+08\end{array}$ & $\begin{array}{l}{[001],[100],[101]} \\
{[001],[100],[101]}\end{array}$ & $\begin{array}{c}100 \\
\\
38 \\
20 \\
100 \\
100 \\
100 \\
100 \\
37 \\
\end{array}$ & $\begin{array}{l}50 \\
37 \\
73 \\
31 \\
85 \\
27\end{array}$ \\
\hline
\end{tabular}

${ }^{a}$ CML section number. ${ }^{b}$ Dislocation density; areas with no dislocations assigned an arbitrary small value to permit calculation of a geometric average.

${ }^{c}$ FFB $=$ free / (free + bound) dislocation ratio. ${ }^{d}$ Length of $\mathbf{b}=[001]$ dislocations in screw orientation compared to other orientations; includes more

dislocations than in areas with formal determination of Burgers vectors (listed in Burgers vector column), as $\mathbf{b}=[001]$ dislocations can usually be identified by their morphology (i.e., extended loop structure). 
olivine regions
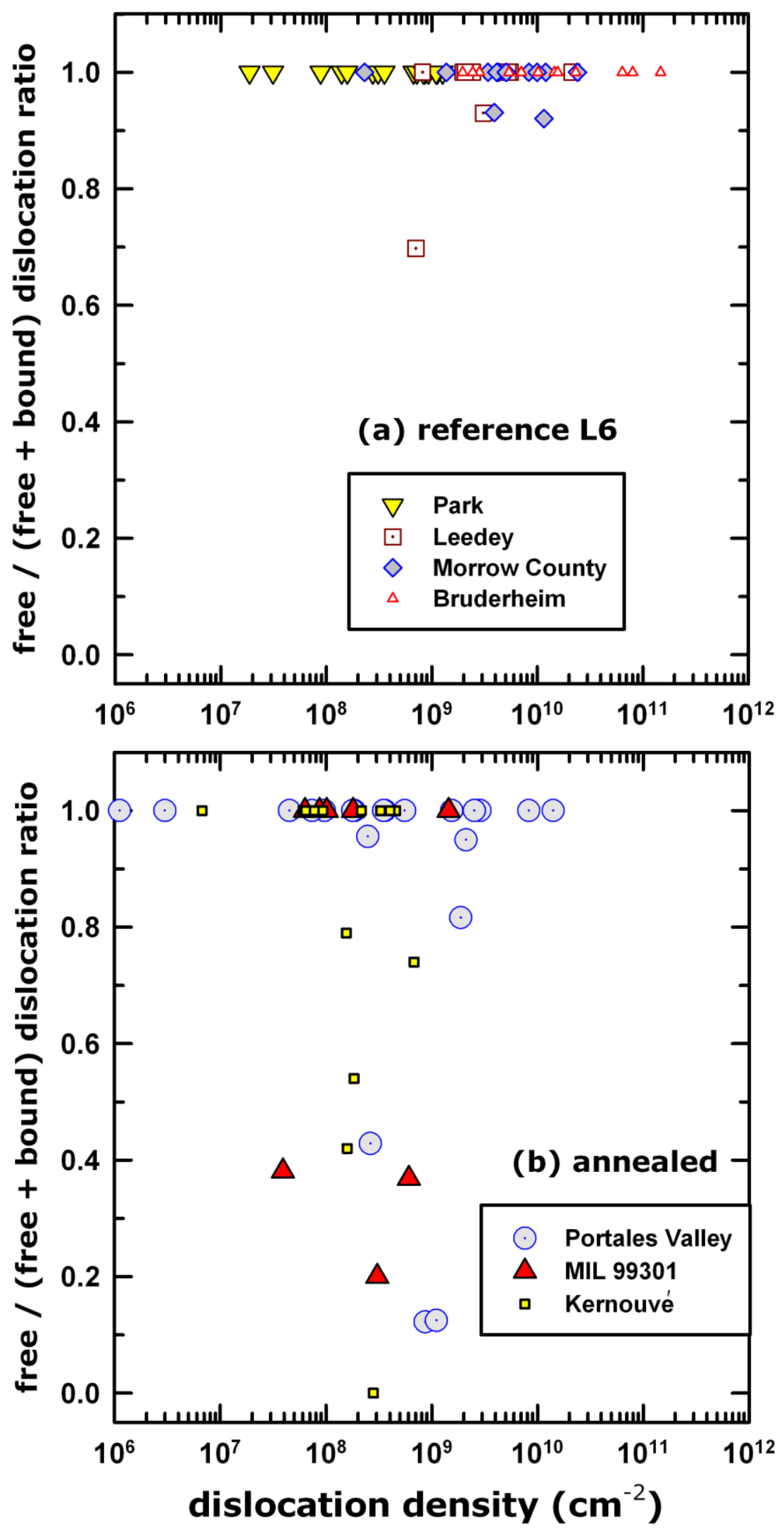

Fig. EA-1. Microstructure data (dislocation density, and free/(free+bound) $=$ FFB dislocation ratio) for individual olivine TEM areas in (a) reference L6 chondrites and (b) annealed $\mathrm{H}$ and $\mathrm{LL}$ chondrites. Contrary to the situation for meteorites as a whole, there is no correlation between dislocation density and FFB ratio on the scale of individual TEM areas. If dislocation annihilation occurred during the formation of subgrain boundaries, the dislocation densities of areas with lower FFB would have been higher initially. Together with maximum dislocation densities and dislocation densities in regions with high FFB, these data can be interpreted to indicate that overall dislocation densities prior to recovery were higher initially for the annealed S1 chondrites.

[color in web] 